\title{
Systematic Review of the Roost-Site Characteristics of North American Forest Bats: Implications for Conservation
}

\author{
Evan C. Drake ${ }^{1, *}$, Sarah Gignoux-Wolfsohn ${ }^{2}\left(\mathbb{D}\right.$ and Brooke Maslo ${ }^{1(1)}$ \\ 1 Department of Ecology, Evolution and Natural Resources, Rutgers, The State University of New Jersey, \\ New Brunswick, NJ 08901, USA; brooke.maslo@rutgers.edu \\ 2 Smithsonian Environmental Research Center, Edgewater, MD 21037, USA; gw.sarah@gmail.com \\ * Correspondence: evan.drake@rutgers.edu
}

Received: 30 January 2020; Accepted: 14 February 2020; Published: 18 February 2020

\begin{abstract}
Continued declines in North American bat populations can be largely attributed to habitat loss, disease, and wind turbines. These declines can be partially mitigated through actions that boost reproductive success; therefore, management aimed at promoting availability of high-quality roosting habitat is an important conservation goal. Following the principles of the umbrella species concept, if co-occurring species share similar roost-tree preferences, then management practices targeting one species may confer conservation benefits to another. We conducted a systematic review of roost-site characteristics of thirteen species inhabiting eastern temperate forests to: (1) synthesize existing knowledge across species; (2) assess niche overlap among co-occurring species; and (3) evaluate the potential for currently protected species to serve as conservation umbrellas. We performed multivariate ordination techniques to group species based on the seven most-reported roost-site characteristics, including tree species, diameter at breast height, tree health, roost type, tree height, canopy closure, and roost height. Species sorted into three roosting guilds: (1) southern wetland inhabitants; (2) foliage specialists; and (3) dead tree generalists. Myotis septentrionalis and Perimyotis subflavus had significant roost-niche overlap with five and four other species respectively, and their existing protections make them suitable umbrellas for other bats in the North American eastern temperate forests.
\end{abstract}

Keywords: bats; forests; conservation; review; roost; habitat; umbrella species

\section{Introduction}

Bats are the most widely distributed land mammal globally, inhabiting every continent except Antarctica [1]. Bats are also one of the most speciose mammalian groups, second only to rodents [2], encompassing $>1400$ species and comprising 20\% of all mammals on Earth [3]. They range in size from the bumblebee bat, Craseonycteris thonglongyai, with a wingspan of $\sim 170 \mathrm{~mm}$ and weighing $\sim 2 \mathrm{~g}$ [4], to the golden crowned flying fox, Acerodon jubatus, with a wingspan of $\sim 1.6 \mathrm{~m}$ and weighing over $1 \mathrm{~kg}$ [5]. This tremendous diversity allows bats to exploit several niches across a variety of ecosystems, providing many ecosystem services [6], including insect pest management [7-9], pollination (e.g., $[10,11])$, and seed dispersal $[12,13]$. Their economic value to the U.S. agricultural industry has been estimated at $\$ 22.9$ billion US dollars annually [14], and they are critical to the socioeconomic stability of small-scale agricultural enterprises globally [11,15].

Despite their importance, bats are in decline across much of the world; $15 \%$ of bat species are considered "threatened" by the International Union for Conservation of Nature [16]. An additional $18 \%$ are "data-deficient", and 57\% have unknown population trends, which results in a staggering 
$80 \%$ of global bat species with risk of extinction [16]. The number of species in need of conservation attention renders species-specific actions impractical at a large scale, making the development of management practices benefitting multiple species an important goal [17]. The use of umbrella species (a species whose conservation benefits co-occurring species and/or an ecosystem) may be a practical way to increase the number of bats receiving conservation benefits [18-20]; yet, few studies evaluate the potential of bats as conservation umbrellas (but see $[21,22]$ ). Successful selection of conservation umbrellas requires a quantitative evaluation of species' habitat characteristics and geographic distribution [23,24], as well as a standardized review of explicit relevant criteria [25]. Some bat species are already under regulatory protection; thus, understanding their potential to serve as conservation umbrellas is an important first step in prioritizing limited conservation resources across this large and diverse taxonomic group.

In eastern North America, bat populations are still being impacted by the fungal pathogen, Pseudogymnoascus destructans, the cause of white-nose syndrome [26-28]. In addition to significant white-nose induced declines, insectivorous bats within this region are affected both directly and indirectly by pesticides and insect resistant crop strains [29,30]. In addition, wind turbines cause significant mortality [31], with estimates of up to 500,000 bats per year in North America alone [32-34]. As urbanization continues to reduce the natural areas that bats rely on for foraging and roosting [35], efficiently managing bat habitat is especially critical [36]. In particular, preserving or creating high-quality roosting sites is critical for maximizing bat diversity and abundance [37]. During the spring and summer, many bat species make extensive use of tree roosts for giving birth and raising pups [38]. These maternity roosts are vital resources for female bats as they exit hibernation and begin expending energy to rear their young [39]. Because of their importance, many studies of roost-site characteristics have been conducted. Existing studies of roost-site characteristics tend to focus on a single site or species (e.g., [40,41]). Accurately synthesizing these data and comparing the roosting niche of forest-dwelling bats may provide a reliable reference for multi-species habitat management, as well as identifying candidate umbrella species.

Here, we conduct a systematic review of the roost-site characteristics of bat species occurring within North American eastern temperate forests, an ecoregion that dominates the mid- and southeastern half of the continent [42]. Our primary objectives are to: (1) synthesize existing knowledge across species; (2) assess niche overlap among co-occurring species; and (3) evaluate the potential for currently protected species to serve as conservation umbrellas. We then discuss the implications of our analyses to bat conservation in North America.

\section{Materials and Methods}

\subsection{Study Region and Species}

Our study area consisted of approximately 2,723,400 $\mathrm{km}^{2}$ of eastern temperate forest (Figure 1), as described by the U.S. Environmental Protection Agency's ecoregion level 1, type 8 [42]. Eastern temperate forests are characterized by diverse forest cover, seasonal temperature changes, and precipitation that is relatively evenly distributed throughout the year [43]. The ecoregion extends from eastern Texas and northern Florida, USA in the south to Ontario and Quebec, CA in the north. Eastern temperate forest primarily occurs within the United States, with coverage in 34 states, while only $\sim 0.5 \%$ of the ecoregion occurs in the Canadian Provinces of Quebec, Ontario, Prince Edward Island, New Brunswick, and Nova Scotia $\left(\sim 11,700 \mathrm{~km}^{2}\right)$.

There are 17 bat species with geographic ranges that overlap our study region. Because our focus was on tree roost-site characteristics, we excluded bats that primarily roost in caves, mines, or rocks [44]. Therefore, we reviewed the roost-site characteristics of the 13 remaining eastern temperate forest bat species (Table 1). 


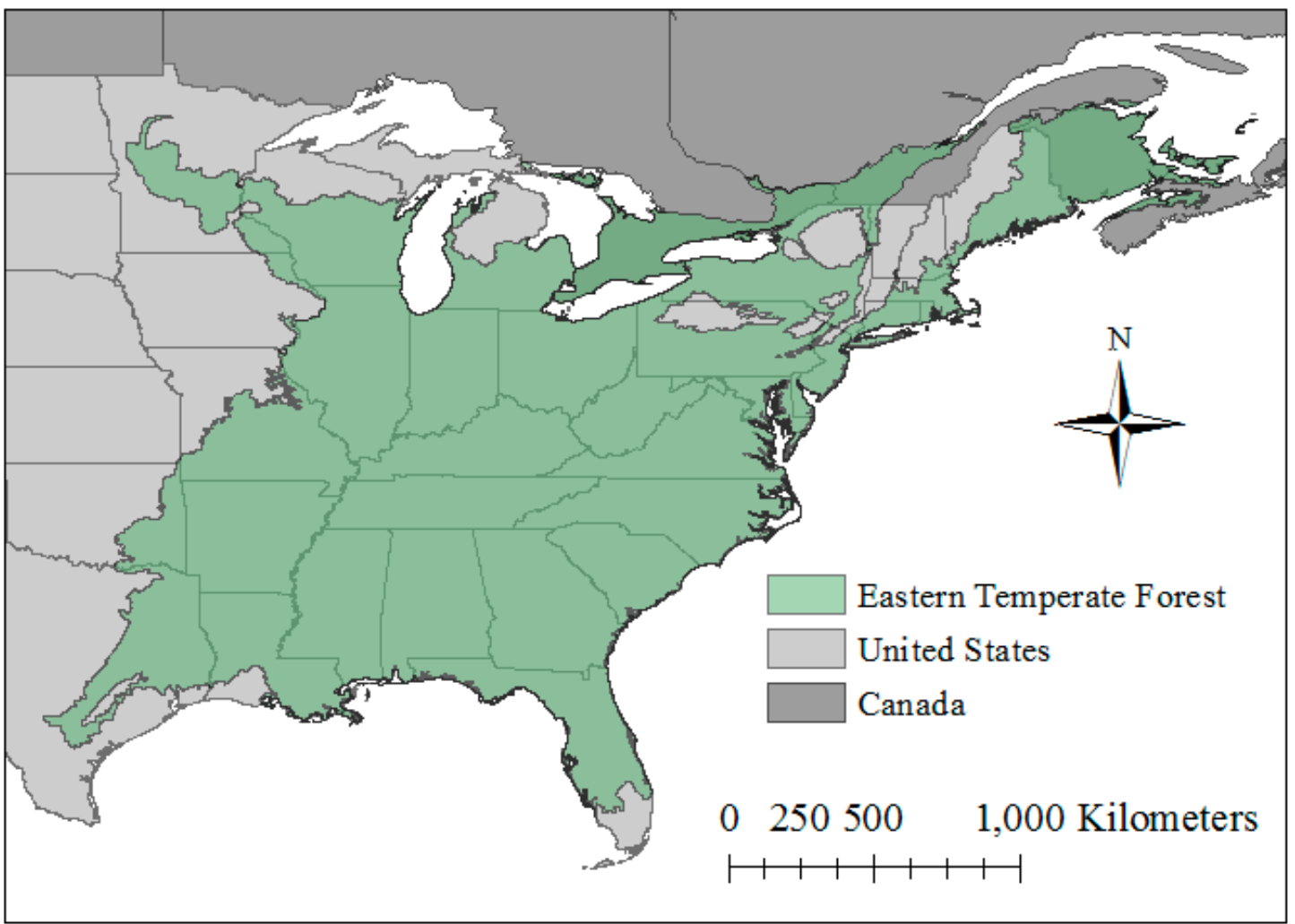

Figure 1. Eastern temperate forest ecoregion of North America. The green shaded area represents the geographic extent from which we included studies.

Table 1. Tree-roosting bat species occurring in eastern temperate forests of North America, and their global and federal conservation status as designated by the International Union for Conservation of Nature (IUCN) [45], United States Fish and Wildlife Service (USFWS), and Canadian Wildlife Service (CWS) [46].

\begin{tabular}{ccccc}
\hline Latin Binomial & Common Name & IUCN $^{\mathbf{1}}$ & USFWS $^{2}$ & CWS $^{2}$ \\
\hline Corynorhinus rafinesquii & Rafinesque's big-eared bat & LC & NL & NL \\
Eptesicus fuscus & big brown bat & LC & NL & NL \\
Lasionycteris noctivagans & silver haired bat & LC & NL & NL \\
Lasiurus borealis & eastern red bat & LC & NL & NL \\
Lasiurus cinereus & hoary bat & LC & NL & NL \\
Lasiurus intermedius & northern yellow bat & LC & NL & NL \\
Lasiurus seminolus & Seminole bat & LC & NL & NL \\
Myotis austroriparius & southeastern myotis & LC & NL & NL \\
Myotis lucifugus & little brown bat & EN & UR & EN \\
Myotis septentrionalis & northern long-eared bat & NT & TH & EN \\
Myotis sodalis & Indiana bat & NT & EN & NL \\
Nycticeius humeralis & evening bat & LC & NL & NL \\
Perimyotis subflavus & tri-colored bat & VU & UR & EN
\end{tabular}

${ }^{1}$ LC = Least Concern, NT = Near Threatened, VU = Vulnerable, EN $=$ Endangered $;{ }^{2} \mathrm{NL}=$ Not Listed, UR = Under Review, $\mathrm{TH}=$ Threatened, $\mathrm{EN}=$ Endangered.

\subsection{Data Sources and Search Strategy}

We used ISI Web of Science, Science Direct, and Google Scholar to generate a database of potential studies for inclusion in our systematic review of tree roost-site characteristics of eastern temperate forest bats. For each species, we used the search terms: "<Latin name $>$ AND roost" within each search engine for a total of 39 searches. Because Perimyotis subflavus received a new taxonomic classification in 1984 [47], we included its former name, Pipistrellus subflavus, to ensure that we incorporated all existing 
relevant datasets. Google Scholar returned several thousand results for each species-specific search, but the relevance of each hit noticeably declined by approximately the $100^{\text {th }}$ article. Accordingly, for each species, we considered only the first 200 Google Scholar hits in addition to all returns for ISI Web of Science and Science Direct.

The search returned 2564 unique references, which we then screened for relevance using the following a priori criteria: the study (1) occurred within the eastern temperate forest ecoregion; (2) was published between 1990-2018; and (3) contained information on the tree roost-site characteristics of one or more of the thirteen target species. We first filtered search returns by title, eliminating studies obviously irrelevant to our study topic. We filtered remaining studies by reading the abstracts and assessing whether they met the criteria listed above. We then read the remaining studies to extract data. Where studies measured roost-site characteristics of multiple species, we treated the species-specific datasets separately.

\subsection{Systematic Review}

We counted number of datasets published for each species, as well as the number of studies conducted in each state/province. For studies with data pertaining to two or more focal species, we considered them to be separate datasets in our count of species' totals. When recording the number of studies published in each state/province, every study was only counted once, regardless of how many datasets a study contained.

For each study, we recorded all reported variables of roost tree/site and subsequently narrowed down our study to the seven most-reported variables: tree genus, diameter at breast height (dbh), tree health, roost type, tree height, canopy closure, and roost height.

For continuous variables, we calculated the pooled mean for each of the 13 species weighted by the dataset sample sizes by multiplying the mean value reported in each dataset by the sample size, adding the products, and then dividing by the number of roost trees reported for each species per dataset (Equation (1)).

$$
\operatorname{Mean}_{i}=\frac{\sum_{i}\left(N_{\text {dataset }} * \text { Mean }_{\text {dataset }}\right)}{\sum_{i}\left(N_{\text {dataset }}\right)}
$$

where $i=$ species.

We then calculated a pooled variance for each of the weighted means based on the standard deviations (or converted standard error) reported in the datasets extracted from the studies.

Because reporting of qualitative roost-site characteristics differed slightly in many studies, we created three standardized categorical variables under which to incorporate non-quantitative roost-site descriptions into our analysis: tree health, roost type, and tree genus. The majority of studies classified roost trees as either dead or alive; and, in few cases, the roost site was located within a dead portion of a living tree. We elected to reclassify roost trees as dead (no foliage or living tissue), partially dead (one or more dead branches and/or trunks), and live. As a representative way to assess species-specific tree health preferences, we calculated the percent of dead roost trees by dividing the number of dead roost trees by the total number of roost trees for each species.

We defined roost type as the specific tree feature used by roosting bats, which included exfoliating bark (bark peeling away from the main bole or branch of the tree), cavities (visible holes in the wood), crevices (splits in the wood) and foliage (clumps of leaves on the tree, either dead or alive). For each dataset, we recorded how many roosts were in each of these four categories. Because the majority of species either roosted exclusively in foliage, or never roosted in foliage, we quantified roost type as the percentage of roosts per dataset that were in foliage. Foliage roosts tend to be away from the large branches and bole of the tree, distinguishing them from the other three roost types.

We also recorded the genus of each roost tree used by bats. Because of the broad taxonomic range of trees used as roosts, and the variation in regional species composition, we simplified these categories more broadly into either deciduous or coniferous trees and calculated the percentage of roosts in deciduous trees for subsequent analyses. 


\subsection{Assessment of Potential Umbrella Species}

While there is no unified consensus in evaluating the efficacy of conservation umbrellas across taxa, ecosystems, or spatiotemporal scales [25], good candidates should exhibit a high degree of spatial overlap with their target group, thus affording habitat protections across a wide geographic range $[18,48]$. Species should also select habitat (in this case, roost trees) with similar characteristics as their focal group [19,49]. From a practical standpoint, species that already carry conservation protections may be effective umbrella species if they satisfy the above-mentioned spatial and niche overlap criteria [50]. We, therefore, evaluated the conservation umbrella potential of the thirteen species in this study based on three criteria: (1) existing regulatory protection; (2) degree of niche overlap; and (3) degree of spatial overlap.

To assess niche overlap among species, we first performed an ANOVA of the means of the seven most-reported variables identified in the systematic review to test for significant differences among roost-site characteristics. For statistically significant results, we performed pairwise Tukey's honest significant difference (Tukey HSD) tests to identify differences between species. We interpreted statistically insignificant ANOVAs and Tukey HSDs as an overlap in roosting niche, operating under the null hypothesis that there is no difference among/between the species for the target roost-site characteristic.

We then performed a series of multivariate statistical ordination techniques to identify potential roosting groups based upon shared roost-tree preferences. Not all studies reported data for all variables. Canopy closure and roost height were reported in $40 \%$, while tree height and dbh were reported in $65 \%$ and $90 \%$ of the studies, respectively. To address missing values in our dataset, we pulled random numbers from a normal distribution based on the pooled mean and the pooled standard deviation estimated from the standard deviations and means of the full data set. We then imputed missing values for the four continuous variables using the pooled mean for each variable and each species. The pooled variance associated with that mean created a normal distribution from which to sample. In one case, no data on canopy closure or tree height were found within the dataset included for Lasionycteris noctivagans. In this case, the mean canopy closure was taken from a publication outside of eastern temperate forests [51].

Using the imputed dataset, we performed a cluster analysis using Ward's method [52]. The analysis generated a dendrogram using hierarchical clustering with $p$-values via multiscale bootstrap resampling in R [53] using the "pvclust" package [54]. We used the unit interval to standardize our units between 0 and 1 because the roost-site characteristics differed by orders of magnitude. We also performed a principal component analysis with the correlation matrix of the seven roost-site characteristics in R. Similar to the unit interval, using the correlation matrix scales the data when they vary by orders of magnitude. Finally, we used a discriminant function analysis of the raw, non-standardized data to visualize the species' roost tree preferences in 2-dimensional space. The three multivariate analyses allowed us to visualize the mathematical distance between the species in terms of their roosting niche; those with poor separation can be considered to have a high degree of niche overlap with each member of their group [55].

To evaluate spatial overlap among species, we downloaded species' range maps from the IUCN website [45]. We clipped each range map to the size of the eastern temperate forest ecoregion and then converted them into geographic information system (GIS) raster layers with a $1 \mathrm{~km}^{2}$ cell size. Within each group of bats identified by our multivariate analyses, we used the raster layers to quantify range overlap between species in a pairwise manner. We added the raster layers together using Map Algebra in ArcGIS (version 10.2.2) to obtain the number of cells that overlap for each species pairing. We quantified spatial overlap by dividing the number of cells occupied by both Species A and Species $B$ by the number of cells occupied by either species A or Species B, resulting in a percentage of range overlap. We used the measurements of overlapping area to calculate how much of any given species' range is contained within the range of another. 


\section{Results}

\subsection{Search Results}

In total, 95 studies [41,56-149] met our criteria for data extraction (Figure 2). Some of the retained studies included data for two or more focal species; therefore, our systematic review consisted of 116 datasets describing 4908 roost trees.

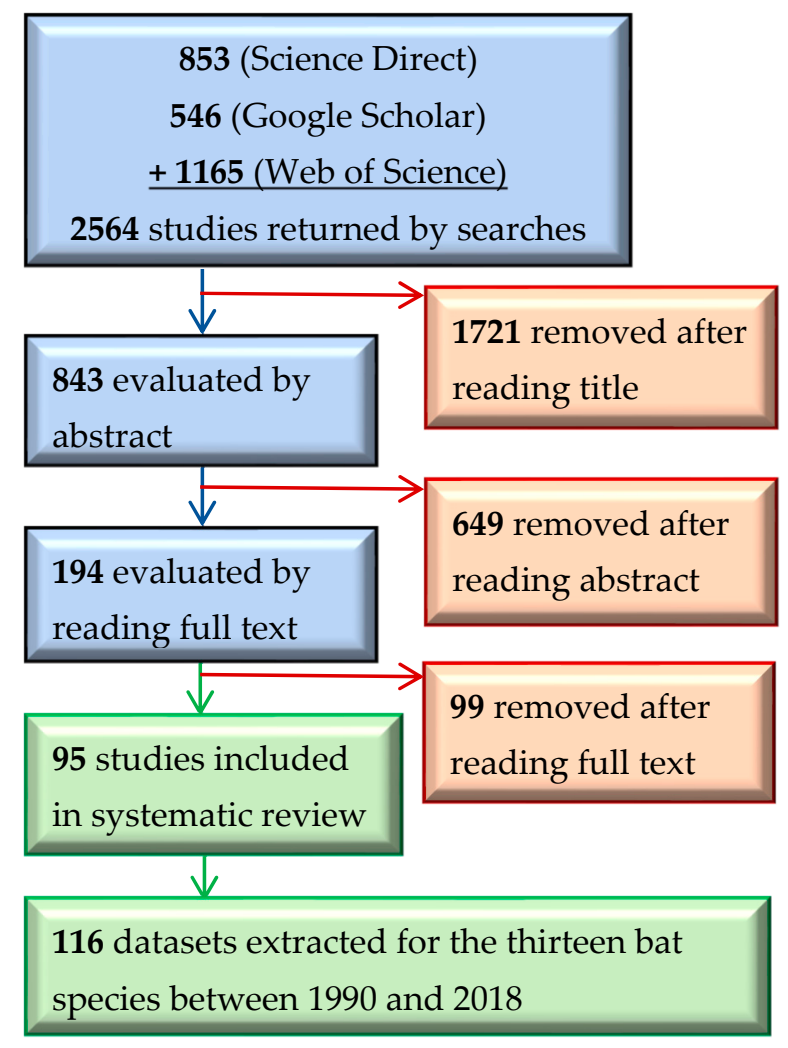

Figure 2. Flowchart of the search strategy and process for identifying studies for inclusion in the systematic review.

The number of datasets pertaining to each focal species ranged between 1-27. The two most well-studied species were Myotis sodalis (27 datasets describing 1375 roost trees) and M. septentrionalis (19 datasets describing 1094 roost trees). Six bat species encompassed $>10$ datasets each, while the remaining seven species had six or fewer. Roost-site characteristics of both M. lucifugus and Lasiurus intermedius were described in only two datasets each (containing 68 and 21 roost trees, respectively), and Lasionycteris noctivagans returned a single dataset of 28 roost trees. Lasiurus cinereus had the fewest total roost trees $(n=17)$ drawn from three datasets.

Nearly 39\% of the studies (37 of 95) were conducted in the four U.S. states of Arkansas (11 studies), Indiana (10 studies), South Carolina (eight studies), and Kentucky (eight studies; Figure 3). Nine U.S. states returned a single study; nine additional states returned zero studies. Only two Canadian studies were included in this review; one from New Brunswick [65] and one from Prince Edward Island [88], both focusing on Myotis septentrionalis.

\subsection{Summary of Roost-Site Characteristics}

The seven most-reported variables were tree genus (92 out of 95 studies; Figure 4), dbh (86 studies), tree health (76 studies), roost type (74 studies), tree height (66 studies), canopy closure (43 studies), and roost height (38 studies). The next most-reported variable was the distance of the roost tree to the nearest source of water (30 studies). However, those 30 studies only contained information on seven of 
the thirteen focal species of this systematic review; thus, we used only the first seven most frequently reported variables for further analyses of niche overlap, for which there were data for almost all species.

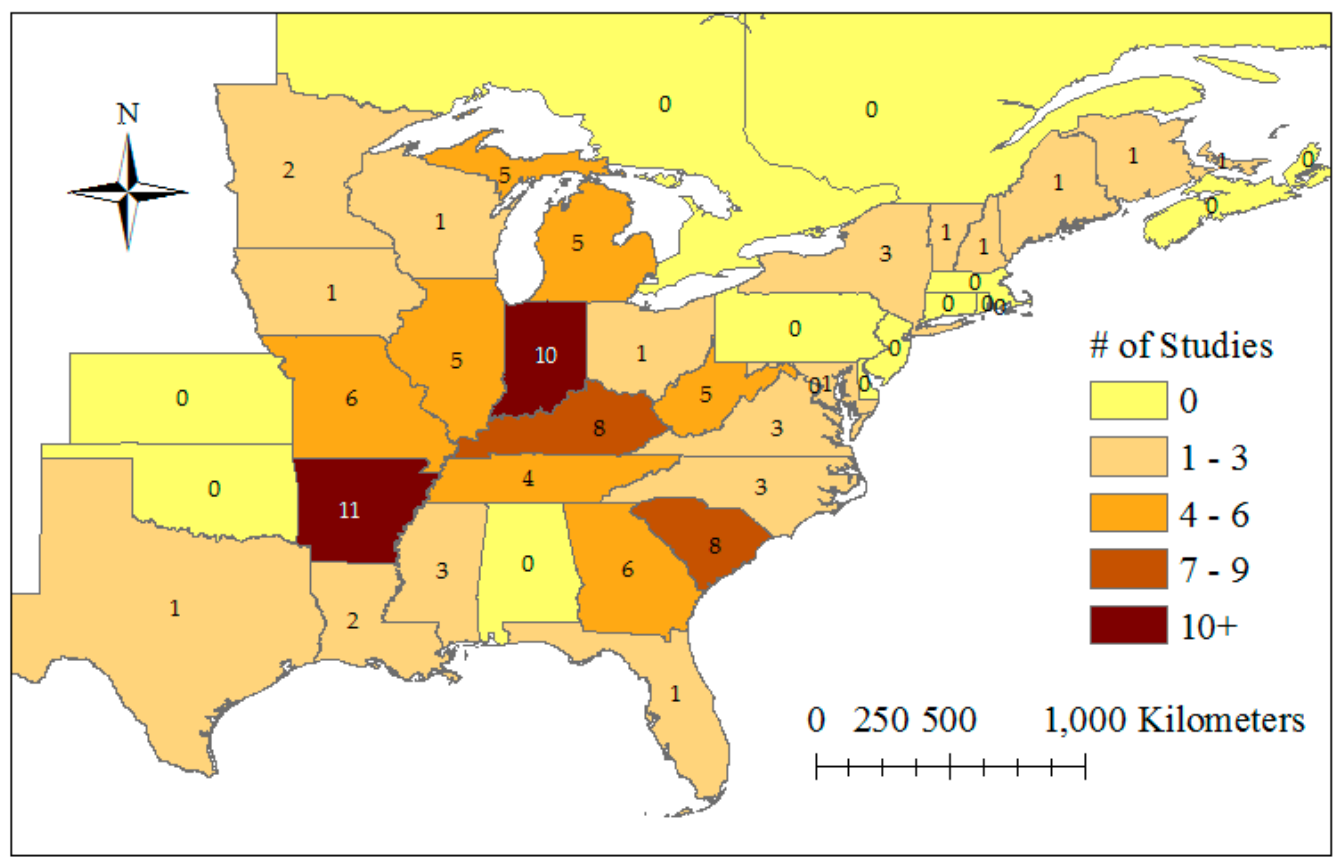

Figure 3. The number of studies $\left(\mathrm{N}_{\text {total }}=95\right)$ included in our review that were published in each U.S. state or Canadian province within the eastern temperate forest ecoregion.

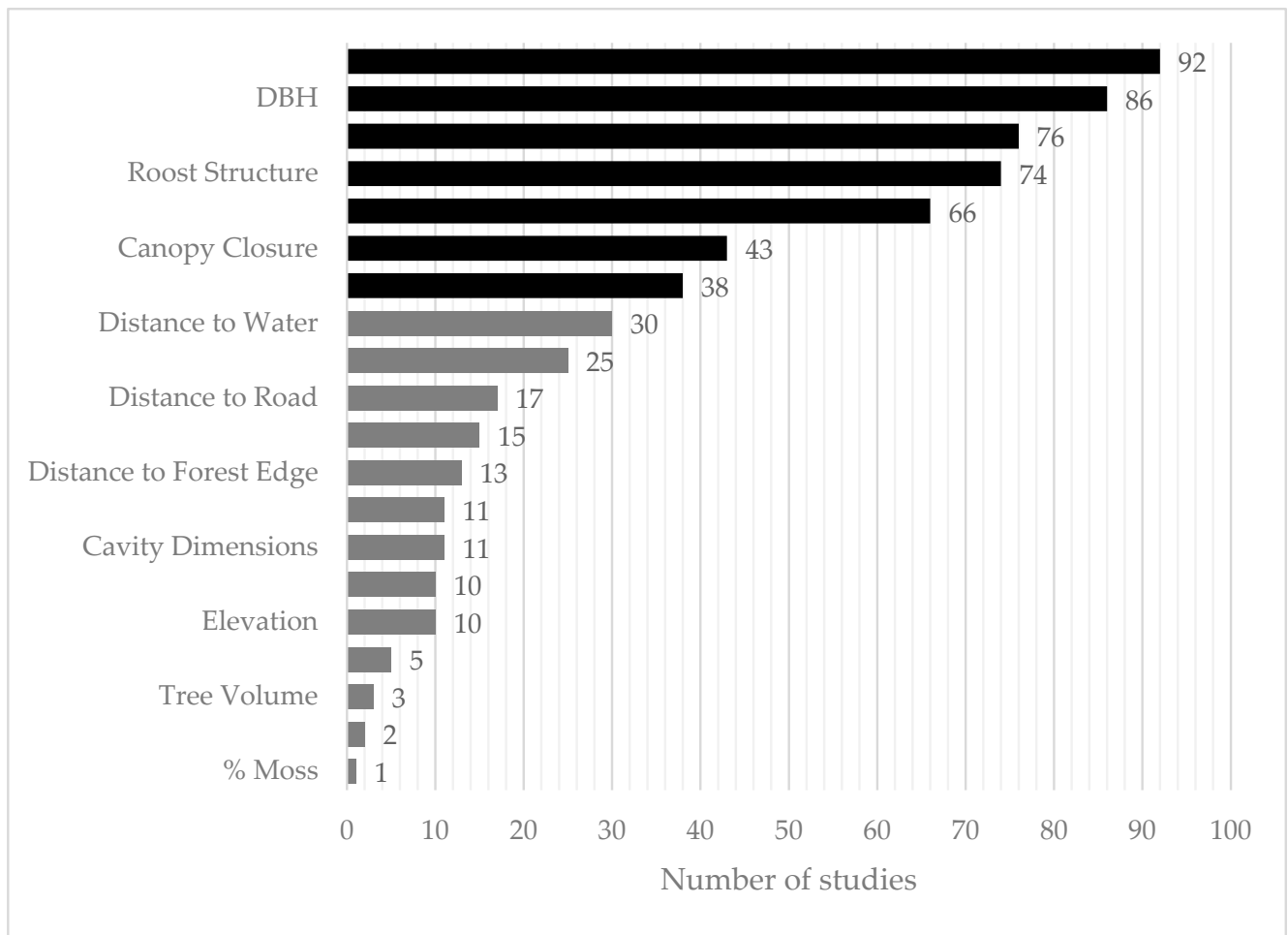

Figure 4. Frequency distribution of the number of studies reporting data on each predictor of tree roost sites. Black bars indicate the roost tree characteristics used in our analysis of niche overlap.

Mean dbh, tree height, roost height, and canopy closure for all bats were $44.29 \mathrm{~cm}(\mathrm{~N}=4451)$, $19.25 \mathrm{~m}(\mathrm{~N}=3046), 8.79 \mathrm{~m}(\mathrm{~N}=1621)$, and $67.04 \%(\mathrm{~N}=2325)$, respectively. Nearly $36 \%(\mathrm{~N}=1758)$ of all bats roosted in live trees, $34.5 \%(\mathrm{~N}=1692)$ in dead trees, and $4.1 \%(\mathrm{~N}=202)$ in partially dead 
trees. There were 36 genera of trees used as roosts in total (Figure A1). Myotis austroriparius and Corynorhinus rafinesquii had the greatest mean $\mathrm{dbh}(\mu=80.3, \sigma=9 \mathrm{~cm}$ and $\mu=117.8 \mathrm{~cm}, \sigma=10.9 \mathrm{~cm}$, respectively). The other eleven bats had substantially lower mean dbh, ranging from $26.4-45.5 \mathrm{~cm}$ (Table 2). Roost height varied significantly among the thirteen species, with Lasiurus cinereus roosting the highest above the ground $(\mu=21.1 \mathrm{~m}, \sigma=4.6 \mathrm{~m})$. In contrast, the lowest roosting bats were Myotis austroriparius $(\mu=1.6 \mathrm{~m}, \sigma=1.3 \mathrm{~m})$, L. intermedius $(\mu=2.3 \mathrm{~m}, \sigma=1.5 \mathrm{~m})$. Canopy closure was greatest for $M$. austroriparius ( $\mu=87.5 \%, \sigma=11.5 \%$ ), and the lowest average canopy closure was recorded for Lasionycteris noctivagans at $(\mu=41.5 \%, \sigma=11.9 \%)$. Perimyotis subflavus and the four bats belonging to the genus Lasiurus roosted almost exclusively in foliage on live trees. Myotis austroriparius and Corynorhinus rafinesquii roosted primarily in cavities, and the remaining six roosted mostly in either exfoliating bark or crevices. L. seminolus, Lasionycteris noctivagans, Eptesicus fuscus, and Myotis lucifugus roosted mostly in coniferous trees.

Table 2. A summary of roost tree characteristics for the thirteen species of bats found in eastern temperate forests. Means (and standard deviations) for the four continuous characteristics used in our analyses of the 116 datasets.

\begin{tabular}{|c|c|c|c|c|c|c|c|c|c|c|c|}
\hline \multirow{2}{*}{$\begin{array}{c}\text { Bat Species } \\
\text { Corynorhinus rafinesquii }\end{array}$} & \multicolumn{2}{|c|}{$\mathrm{DBH}(\mathrm{cm})$} & \multicolumn{2}{|c|}{$\begin{array}{c}\text { Tree Height } \\
\text { (m) }\end{array}$} & \multicolumn{2}{|c|}{$\begin{array}{c}\text { Roost Height } \\
\text { (m) }\end{array}$} & \multicolumn{2}{|c|}{$\begin{array}{c}\text { Canopy } \\
\text { Closure }(\%)\end{array}$} & \multirow{2}{*}{$\begin{array}{c}\begin{array}{c}\text { Deciduous } \\
\text { Roosts \% }\end{array} \\
83.4\end{array}$} & \multirow{2}{*}{$\begin{array}{c}\begin{array}{c}\% \text { Dead } \\
\text { Roosts }\end{array} \\
8.4\end{array}$} & \multirow{2}{*}{$\begin{array}{c}\begin{array}{c}\% \text { Foliage } \\
\text { Roosts }\end{array} \\
0.0\end{array}$} \\
\hline & 117.8 & $(10.9)$ & 22.4 & $(4.7)$ & 6.3 & $(2.5)$ & 75.2 & $(24.8)$ & & & \\
\hline Eptesicus fuscus & 26.4 & $(5.1)$ & 13.9 & (3.7) & 7.7 & $(2.8)$ & 61 & $(4.9)$ & 22.7 & 86.4 & 0.0 \\
\hline Lasiurus borealis & 29.6 & $(5.4)$ & 19 & (4.4) & 14.4 & (3.8) & 81 & $(17.5)$ & 81.0 & 0.2 & 80.3 \\
\hline Lasiurus cinereus & 35.2 & $(5.9)$ & 22.4 & $(4.7)$ & 21.1 & $(4.6)$ & 80 & (16.3) & 41.2 & 0.0 & 100.0 \\
\hline Lasiurus intermedius & 45.5 & $(6.7)$ & 15.4 & (3.9) & 2.3 & $(1.5)$ & 71.2 & $(17.8)$ & 100.0 & 0.0 & 100.0 \\
\hline Lasiurus seminolus & 40.2 & (6.3) & 26 & (5.1) & 16.3 & $(4)$ & 71.8 & $(17.2)$ & 5.4 & 0.0 & 62.5 \\
\hline Lasionycteris noctivagans & 33.1 & $(5.8)$ & 26.7 & (7.8) & 5.1 & $(2.3)$ & 41.5 & (11.9) & 17.9 & 0.0 & 0.0 \\
\hline Myotis austroriparius & 80.3 & (9) & 23.1 & $(4.8)$ & 1.6 & (1.3) & 87.5 & (11.5) & 79.0 & 11.1 & 0.0 \\
\hline Myotis lucifugus & 40 & $(6.3)$ & 10.7 & (3.3) & 8.4 & $(2.9)$ & 62.4 & (19.4) & 22.1 & 23.5 & 0.0 \\
\hline Myotis septentrionalis & 35.4 & $(5.9)$ & 16.8 & (4.1) & 7.9 & $(2.8)$ & 67.7 & $(25.3)$ & 76.8 & 41.9 & 0.0 \\
\hline Myotis sodalis & 37.7 & $(6.1)$ & 18.3 & (4.3) & 10.1 & $(3.2)$ & 52.5 & $(34.9)$ & 64.9 & 60.9 & 0.0 \\
\hline Nycticeius humeralis & 39.4 & $(6.3)$ & 18 & $(4.2)$ & 11.8 & $(3.4)$ & 67 & $(26)$ & 49.6 & 39.3 & 0.2 \\
\hline Perimyotis subflavus & 27.5 & (5.2) & 20 & (4.5) & 13.7 & $(3.7)$ & 49.1 & $(29.7)$ & 89.5 & 33.1 & 100.0 \\
\hline
\end{tabular}

\subsection{Niche Overlap of Eastern Temperate Forest Bats}

The three multivariate ordination analyses consistently classified bats into three groups. Eptesicus fuscus, Lasionycteris noctivagans, Nycticeius humeralis, Myotis sodalis, M. septentrionalis, and M. lucifugus comprise the largest group. The second group contains Perimyotis subflavus, Lasiurus seminolus, L. cinereus, L. borealis, and L. intermedius. Finally, Corynorhinus rafinesquii and Myotis austroriparius are paired together. Discriminant functions 1 and 2 of the DFA explained $90.4 \%$ of the variation seen in the data (Table 3, Figure 5). Bootstrapped cluster analysis using Ward's method produced a dendrogram that supported the DFA, and the approximately unbiased p-values associated with the nodes ranged from $69-100 \%$ (Figure A2). The PCA plot also agreed with the group generated by the dendrogram and the DFA (Figure A3).

Six of the seven variables used in our analyses were statistically different across species $(p<0.01)$, with the sole exception being canopy closure $(p=0.206, \mathrm{df}=12, \mathrm{~F}=1.41)$. The Tukey HSD tests identified differences between species (Table A1). All significant differences in dbh can be attributed to either Corynorhinus rafinesquii or Myotis austroriparius roosting in trees with significantly greater mean dbh compared to other species. There were no significant differences between $C$. rafinesquii and $M$. austroriparius themselves $(p=0.149)$. C. rafinesquii and $M$. austroriparius also tended to roost lower on the tree than most other species. For example, Lasiurus cinereus had the highest mean roost height, and it differed significantly from both C. rafinesquii $(p=0.002)$ and M. austroriparius $(p=0.0003)$. The latter also roosted significantly lower than bats such as L. seminolus $(p=0.0146)$ and Perimyotis subflavus $(p=0.006)$. The most divisive characteristic was the percentage of roosts in foliage, with most species either roosting exclusively in foliage, or never in foliage. All differences in percentage of foliage roosts are attributed to the four Lasiurus species and P. subflavus. 
Table 3. The coefficients for the seven variables for the two discriminant functions that explained $90.4 \%$ of the variation in the data for the roost tree characteristics of the thirteen species of tree-roosting bats in eastern temperate forests.

\begin{tabular}{cccccccc}
\hline $\begin{array}{c}\text { Discriminant } \\
\text { Function }\end{array}$ & $\begin{array}{c}\text { Canopy } \\
\text { Closure }\end{array}$ & $\begin{array}{c}\text { Tree } \\
\text { Height }\end{array}$ & $\begin{array}{c}\text { Roost } \\
\text { Height }\end{array}$ & DBH & $\begin{array}{c}\text { \%Deciduous } \\
\text { Roosts }\end{array}$ & $\begin{array}{c}\text { \%Dead } \\
\text { Roosts }\end{array}$ & $\begin{array}{c}\text { \%Foliage } \\
\text { Roosts }\end{array}$ \\
\hline DF 1 (69.02\%) & -0.00002 & -0.00086 & 0.00336 & -0.0025 & 0.0336 & -0.0382 & 0.6683 \\
DF 2 (21.38\%) & 0.00177 & 0.00179 & -0.00713 & 0.00557 & -0.1103 & -0.1491 & 0.17786 \\
\hline
\end{tabular}

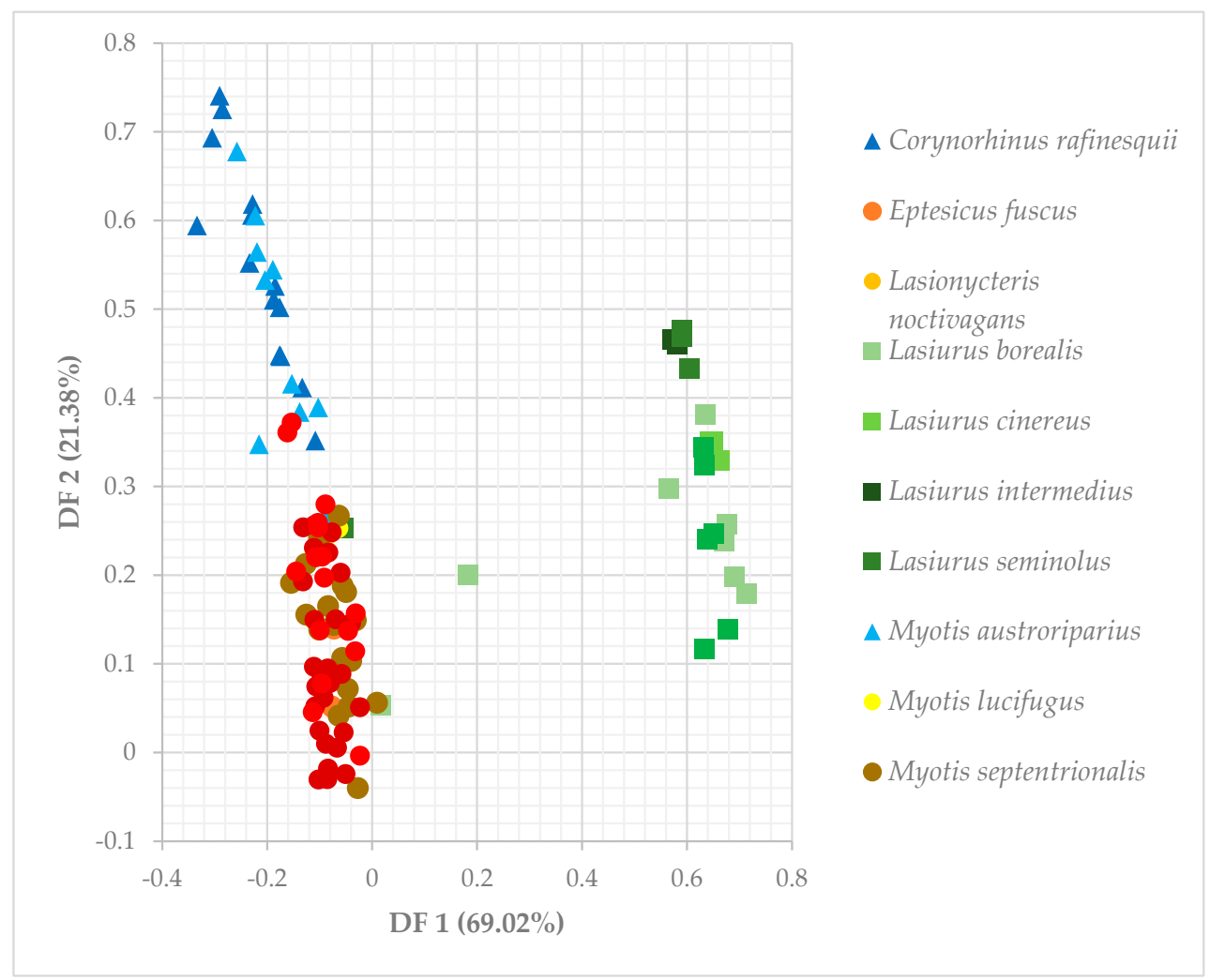

Figure 5. Discriminant function analysis of roost-site characteristics of North American eastern temperate forest bats indicates that the thirteen bat species separate into three distinct groups.

\subsection{Spatial Overlap Among Eastern Temperate Forest Bats}

The percentage of eastern temperate forest contained within the geographic range of each species varied between $20.3-93.7 \%$. Lasiurus cinereus, L. borealis, and Lasionycteris noctivagans were the most widespread species, each occupying $>93 \%$ of the eastern temperate forest. Perimyotis subflavus $(\sim 89 \%)$, Eptesicus fuscus ( $\sim 87 \%)$, Myotis lucifugus ( $82 \%)$, Nycticeius humeralis ( 72\%), and M. septentrionalis $(\sim 67 \%)$ were also well distributed across the ecoregion. M. sodalis and Corynorhinus rafinesquii had smaller ranges that each covered $\sim 44 \%$ of the ecoregion. Lasiurus seminolus, Myotis austroriparius, and $L$. intermedius were the most geographically restricted species, with ranges that overlapped with eastern temperate forest by $35 \%, 28 \%$, and $20 \%$, respectively.

At least one species within each roosting group encompassed $>90 \%$ of the total range of its group members. C. rafinesquii has a range that contains $\sim 92 \%$ of $M$. austroriparius's range (Table 4 , Group 3), while the range of Eptesicus fuscus includes between $90.6-100 \%$ of the range of L. noctivagans, M. lucifugus, M. septentrionalis, and M. sodalis (Table 4, Group 1). Of the species in the remaining group, L. borealis, L. cinereus, and P. subflavus all encompass $>92 \%$ of the ranges of group members (Table 4 , Group 2). In contrast, the federally threatened M. septentrionalis contains an average of $74.3 \%$ of its group members' ranges (Table 4, Group 2). The federally endangered M. sodalis provides just $53.2 \%$ coverage, on average, of its group members' ranges. 
Table 4. Total range for each tree-roosting bat species in eastern temperate forests. Percentage values denote the fraction of a species' range that is encompassed in the habitat area of another species (e.g., 58.5\% of the Corynorhinus rafinesquii's range falls within the range of Myotis austroriparius). "EPFU" = Eptesicus fuscus,

"LANO" = Lasionycteris noctivagans, "MYLU" = Myotis lucifugus, "MYSE" = Myotis septentrionalis, "MYSO" = Myotis sodalis, "NYHU" = Nycticeius humeralis, "LABO" = Lasiurus borealis, "LACI" = Lasiurus cinereus, "LAIN" = Lasiurus intermedius, "LASE" = Lasiurus seminolus, "PESU" = Perimyotis subflavus, "CORA" = Corynorhinus rafinesquii, "MYAU" = Myotis austroriparius.

\begin{tabular}{|c|c|c|c|c|c|c|c|c|c|c|c|c|c|}
\hline Species & EPFU & LANO & MYLU & MYSE & MYSO & NYHU & $L A B O$ & $L A C I$ & $L A I N$ & $L A S E$ & PESU & CORA & MYAU \\
\hline Range $\left(\mathrm{km}^{2}\right)$ & $2,360,598$ & $2,544,272$ & $2,237,050$ & $1,811,663$ & $1,210,854$ & $1,958,280$ & $2,551,433$ & $2,552,372$ & 553,416 & 946,051 & $2,432,854$ & $1,181,713$ & 751,674 \\
\hline \multicolumn{14}{|c|}{ Dead Tree Generalists } \\
\hline E. fuscus & 100 & 90.6 & 97.6 & 97 & 99.9 & 100 & - & - & - & - & - & - & - \\
\hline L. noctivagans & 97.7 & 100 & 94.8 & 99.6 & 99.3 & 87.9 & - & - & - & - & - & - & - \\
\hline M. lucifugus & 92.5 & 83.4 & 100 & 98.1 & 99.4 & 81.7 & - & - & - & - & - & - & - \\
\hline M. septentrionalis & 74.5 & 70.9 & 79.4 & 100 & 86.8 & 60 & - & - & - & - & - & - & - \\
\hline M. sodalis & 51.2 & 47.3 & 53.8 & 58 & 100 & 55.9 & - & - & - & - & - & - & - \\
\hline N. humeralis & 83 & 67.7 & 71.5 & 64.8 & 90.5 & 100 & - & - & - & - & - & - & - \\
\hline \multicolumn{14}{|c|}{ Foliage Specialists } \\
\hline L. borealis & - & - & - & - & - & - & 100 & 98.1 & 100 & 99.9 & 99.1 & - & - \\
\hline L. cinereus & - & - & - & - & - & - & 98.1 & 100 & 92.1 & 95.4 & 98.1 & - & - \\
\hline L. intermedius & - & - & - & - & - & - & 21.7 & 20 & 100 & 55.9 & 22.1 & - & - \\
\hline L. seminolus & - & - & - & - & - & - & 37 & 35.4 & 95.5 & 100 & 38.2 & - & - \\
\hline P. subflavus & - & - & - & - & - & - & 94.5 & 93.5 & 97.1 & 98.2 & 100 & - & - \\
\hline \multicolumn{14}{|c|}{ Southern Wetland Species } \\
\hline C. rafinesquii & - & - & - & - & - & - & - & - & - & - & - & 100 & 91.9 \\
\hline M. austroriparius & - & - & - & - & - & - & - & - & - & - & - & 58.5 & 100 \\
\hline
\end{tabular}




\section{Discussion}

This work presents the most comprehensive and current synthesis of existing knowledge about roost-site characteristics of tree-roosting bats in North American eastern temperate forests. Previous work has elucidated the roosting niche of a subset of bat species in the form of a meta-analysis or power analysis [150-152], as well as bat roosting behavior at a global scale [153]. We have built upon this foundation by examining multiple bat species across a large ecoregion of North America. Our study reveals an inequality in bat research attention. In eastern temperate forests, Myotis sodalis received disproportionate attention, perhaps because of its federal protections in the United States. M. sodalis has been a high-priority research species for over 40 years [154], including studies highlighting habitat [155], foraging [156], and mating [157]. M. septentrionalis is also well-represented in the literature, perhaps because of its high abundance prior to the emergence of white-nose syndrome $[131,158]$.

In contrast to these well-studied species, Eptesicus fuscus, Lasionycteris noctivagans, Lasiurus cinereus, L. intermedius, L. seminolus, and M. lucifugus have fewer than five datasets each. The paucity of datasets may be a product of our study design, as we restricted our focus to studies reporting roost-site characteristics within eastern temperate forests between 1990-2018. Species such as Lasionycteris noctivagans and Lasiurus cinereus have large geographic ranges and do not rely exclusively on eastern temperate forests for summer roosting habitat $[159,160]$. Similarly, Lasiurus intermedius occupies eastern temperate forests only in the northern extent of its range. A large portion of its range is in central America, where they make use of palms and other substrates uncommon in temperate areas [161,162]. Finally, tree-roost publications for E. fuscus and M. lucifugus may be explained by their propensity for roosting in man-made structures $[163,164]$. However, none of the bats included in our review are obligate manmade-structure inhabitants. We chose to include them in our study of tree-roosting bats because they are generalists that will make use of a wide variety of roosting media (including trees) $[165,166]$. Nonetheless, additional studies can increase our understanding of roosting behavior in data-deficient species, as well as refine the precision of measured roost-site characteristics in relatively well-studied species.

The seven most-reported roost-site characteristics used in our analyses are widely applicable and ecologically relevant for determining habitat selection in bats [167]. These variables in general are easily recorded, with many (e.g., tree genus and health, roost type) classified by a visual survey. Other quantitative metrics (e.g., dbh, roost height, canopy closure) can be measured quickly with readily available forestry equipment. In contrast, relatively few studies reported on more specialized roost-site metrics, such as cavity dimensions, microclimate, and tree volume, likely due to the time and effort required for accurate measurement. However, these characteristics can provide valuable insight on the roosting behavior of bats. Specifically, roost microclimate is an important determinant of reproductive success, with female bats tending to prefer warmer sites as maternity habitat $[168,169]$. How tree or roost structure affects microclimate can provide critical guidance for maintaining appropriate roosting sites. Even foliage roosting bat species (e.g., Lasiurus cinereus) will seek clumps of leaves that provide sufficient shelter from the elements [159]. Across studies, simpler measurements were often used as a proxy for more detailed microclimate metrics [170-172]. However, substitute measurements may fail to capture the primary determinants of roost selection. For example, canopy closure is often used as a substitute for solar exposure, an important criterion for maternity colonies [169]. However, an observer on the forest floor may be well-shaded, while the roost is exposed to direct sunlight. Canopy closure can be estimated from the ground [173] or from aerial imagery [174], but perhaps neither accurately represent the canopy closure experienced by the bat while roosting. Instead, properly attached temperature-sensitive radio transmitters could be used to infer roost microclimate characteristics directly [175], rather than estimate based on the relationship between canopy closure, solar exposure, and microclimate.

Relative to the tree scale, landscape-scale characteristics were less reported. Distance from the roost tree to the nearest source of water, forest edge, or corridor were not reported as often as other measurements. If the latitude and longitude of the roost trees were recorded, then these measurements 
can be made remotely, in most cases, with the use of aerial imagery. Easy access to these metrics make them readily available data sources. Preferable roost trees tend to be near water $[106,176]$ and/or corridors [86,177], thus reducing the energetic demands of foraging. While males and nonreproductive females may be less restricted by their biological needs, pregnant and lactating females tend to select roosts with closer proximity to foraging resources [140]. Landscape attributes have significant predictive power when evaluating roost-site suitability [177], and including more data regarding the landscape in which roosts are situated may have provided additional context for the results of our study. However, we did not have enough datasets containing these measurements to explore the topic further.

Our three multivariate analyses classified our focal species into three groups, hereafter roosting guilds, which share ecologically significant roost-site preferences. Approximately $95 \%$ of significant pairwise Tukey HSD tests between roost tree characteristics occurred between bats that were in different guilds (Table A1). There were only four cases of a statistically significant difference within guilds, and they all occurred in the guild containing the foliage specialists. All four within-guild differences pertained to either Lasiurus seminolus or L. intermedius. Three of these differences can be attributed to L. seminolus datasets reporting many roosts in coniferous trees $[111,113,121]$, and the other one is because of the L. intermedius dataset reporting very low roost heights when using Spanish moss [90]. It is unclear whether these differences are reliable, or if they are a product of the small sample size of reported roosts for those species. With few exceptions, the Tukey HSD tests provide additional support to our guild assignments by quantitatively demonstrating the overlap in roosting niches within guilds and the divergence of roosting niches between guilds.

Corynorhinus rafinesquii and Myotis austroriparius comprise the southern wetlands guild, as they share the tendency to roost in cavities of live trees with greater $\mathrm{dbh}$, and they are geographically restricted to the southern portion of eastern temperate forests $[83,178]$. It is worth noting that range data were not included in the multivariate analyses, so the relationship between these two species was evident by roost-site characteristics alone. They both have strong preferences for cavities in large Nyssa aquatica and Taxodium distichum in bottomland-riparian forests [76,137], and they had complete overlap in roost site characteristics as determined by Tukey HSD tests. They each also had at least one significantly different roost characteristic with the other eleven bats in our study (the exception being M. austroriparius, which had no significant differences with M. lucifugus or Lasionycteris noctivagans, two bats outside of its guild).

The dead tree generalist roosting guild consists of Eptesicus fuscus, Lasionycteris noctivagans, Nycticeius humeralis, Myotis sodalis, M. septentrionalis, and M. lucifugus. These bat species all tend to prefer exfoliating bark, cavities, or crevices $[65,123,126,179]$. As the name of the guild suggests, the species here have an affinity for dead or dying trees when selecting a roost $[57,87,122]$. This guild also contains species known to take advantage of manmade structures, E. fuscus and M. lucifugus [180,181]. The bats differ in geographic range from M. sodalis occupying just the central area of the ecoregion, to E. fuscus, L. noctivagans, and M. lucifugus occupying nearly all of it. M. septentrionalis and N. humeralis cover approximately two thirds of the ecoregion, but the former covers the northern area, and the latter covers the southern. The dead tree generalists had high within-guild overlap based on Tukey HSD tests. For example, M. septentrionalis did not significantly differ from its five groupmates, but it had at least one significantly different roost tree characteristic from each bat outside of its group. Aside from L. noctivagans, $M$. austroriparius, and M. lucifugus, no species had completely overlapping roost tree characteristics with any species outside of its guild.

The foliage specialist roosting guild is comprised of Perimyotis subflavus, Lasiurus seminolus, L. cinereus, L. borealis, and L. intermedius. These species are known to roost in clumps of foliage on living trees $[111,124,145]$, and they tended to roost in locations on the tree that were much higher than the other species because most foliage tends to grow towards the top of forest trees. However, Lasiurus intermedius had a much lower roost height than its guildmates. It is uncertain whether this difference is an artefact of small sample size, as only one of the two L. intermedius datasets included in this review 
reported roost height. All bats in that dataset roosted in clumps of low-hanging Spanish moss [90]; therefore, more studies of the roost-site characteristics of L. intermedius will improve our understanding of their niche. L. borealis, L. cinereus, and P. subflavus have broad geographic ranges that nearly include the entirety of the ecoregion. L. intermedius and L. seminolus are more limited to the southern portion of eastern temperate forests. Their preference for southern forests may be related to an energetic demand relating to their thermal physiology or a preference for a certain type of foliage.

The literature suggests that a suitable umbrella species should have a large geographic range with spatial overlap with its guildmates, sufficiently overlapping niche with those guildmates, and ideally with existing protections [50]. Many species fit only one or two of these criteria. For example, the most widespread species within each guild are Lasiurus cinereus, Corynorhinus rafinesquii, and Lasionycteris noctivagans. However, Lasiurus cinereus and Lasionycteris noctivagans are among the least studied species in their respective guilds. Their large ranges are offset by their poorly quantified roosting preferences within eastern temperate forests. Additionally, these three species have no existing protections from the U.S., Canada, or the IUCN making them poor potential conservation umbrellas.

Based upon the synthesized data presented here, M. septentrionalis is the best candidate umbrella for the dead tree generalist roosting guild. While both $M$. sodalis and M. septentrionalis both have existing regulatory protections [182,183], our study supports the conclusions drawn by previous studies that $M$. septentrionalis has more generalist roosting preferences $[68,79,141]$. In addition, $M$. septentrionalis occurs over a wider geographic range than $M$. sodalis $[42,45]$. This species has an acceptable tradeoff between broad spatial range, well-studied generalist roosting niche, and existing protections. Forest management techniques that promote roosting habitat for $M$. septentrionalis will also likely benefit its guildmates at a broad scale. While M. lucifugus has a greater geographic range than either M. septentrionalis or M. sodalis, we found very few studies focusing on its tree-roosting behaviors, and it frequently takes advantage of buildings as roosts instead [180,181]. It is important to note that the tree-roosting protections provided by an umbrella species for this guild would only benefit the Eptesicus fuscus and M. lucifugus individuals that make regular use of trees, and the individuals that roost in rocks or manmade structures may require separate considerations [184].

Taking into consideration its geographic range, existing protections, and its need for conservation attention, we propose Perimyotis subflavus as a conservation umbrella for the foliage-specialist guild. All five species in this guild have no current federal protections in the United States, but P. subflavus is listed as an endangered species in Canada [46], and as "vulnerable" on the IUCN Red List of Threatened Species [45]. P. subflavus is widespread across eastern temperate forests covering approximately $90 \%$ of the ecoregion [42,45], and its range and niche overlap significantly with its guildmates within the ecoregion [45]. There is a recent increase in interest in protecting the species because P. subflavus populations have been negatively impacted by white-nose syndrome [185], leading to it currently being under review for protected status in the United States. If it were to receive those protections, then the four bat species sharing its guild would also experience benefits. Lasiurus borealis also has high spatial overlap and niche overlap with its guildmates, and it is the most well-studied species in its guild.

The southern wetland guild is small, geographically restricted, and behaviorally distinct. Neither of the species in this guild have existing protections. Myotis austroriparius and Corynorhinus rafinesquii did not meet our three criteria for umbrella species status in the context of this study: Spatial overlap with many species, niche overlap with many species, and existing protections. Therefore, we refrain from assessing their potential as umbrella species at this time.

Our guild assignments are based on studies published within eastern temperate forests, most of which are in the United States. Bat species such as Lasiurus cinereus, Myotis lucifugus, and Lasionycteris noctivagans have ranges that extend well beyond eastern temperate forests, while M. sodalis and Lasiurus seminolus have ranges that are mostly contained by the ecoregion. Associations and patterns including those highlighted by our work may be specific to our study region. It is worth noting that the choices of umbrella species described by our study may not necessarily apply to other ecoregions. 
Our study has identified potential applications of the umbrella species strategy in North American bat conservation. The potential umbrella species identified by synthesizing these studies are valuable targets for forest managers and conservation specialists that may be interested in maintaining or creating bat habitat. This study has taken thirteen species, and it has reduced them into three guilds. Bats that share significant aspects of their niche could effectively be treated as a single ecological unit. Actions that benefit one member of the guild should have similar benefits on the other members. For example, if we were to manage a forest in such a way as to increase roosting opportunities for Myotis septentrionalis, then we would also be increasing roosting habitat for species such as M. lucifugus. M. septentrionalis is known to benefit from protecting standing dead trees in forest interiors [186]. Removing dead trees is a common practice in forest management because they could damage healthy trees or property when they fall. Retaining standing dead trees in a natural forest would provide crevices, cavities, and exfoliating bark that would benefit $M$. septentrionalis and the guild underneath its umbrella. M. septentrionalis has also been known to preferentially forage and roost in burned areas after a prescribed burn [187]. However, not all bat species benefit from conventional management techniques. Perimyotis subflavus avoided roosting in areas of active timber harvest [187].

Our results indicate that habitat conservation efforts focused on Myotis septentrionalis and Perimyotis subflavus are of high priority. Within the eastern temperate forests of North America, forest management objectives aimed at maintaining bat roosting habitat can be largely streamlined by focusing on the roost-site requirements of these proposed umbrella species. It is important to note, however, that targeted conservation measures may be needed for ensuring persistence of individual species. As an example, the protection and regeneration of bottomland habitats in the midwestern United States may contribute disproportionately to Indiana bat recovery due to their reliance on hydric habitats [188]. Such finer-scaled directives may be apparent under the conservation umbrella approach.

\section{Conclusions}

Our systematic review of the tree-roosting eastern temperate forest bats of North America revealed three distinct groups exhibiting significant roosting niche overlap. Within these roosting guilds, $M$. septentrionalis and $P$. subflavus emerge as species with high potential to serve as conservation umbrellas for their groups. The existing federal protections of M. septentrionalis (in the U.S. and Canada) and P. subflavus (in Canada), and the probable future protections of P. subflavus in the U.S., further facilitating their potential to confer conservation benefits. However, approximately half of the species reviewed here were not well-represented in the literature. In particular, additional research on tree roost-site selection of Lasionycteris noctivagans, Lasiurus cinereus, and Lasiurus seminolus may refine the inferences drawn from the current body of knowledge. As many bat species are in decline and/or data-deficient, it is crucial that we highlight the need for further study of the ecologically and economically important Chiropterans.

Author Contributions: Conceptualization, E.C.D., S.G.-W. and B.M.; methodology, E.C.D. and B.M.; formal analysis, E.C.D.; investigation, E.C.D.; resources, B.M.; writing—original draft preparation, E.C.D.; writing-review and editing, B.M. and S.G.-W.; supervision, B.M.; All authors have read and agreed to the published version of the manuscript.

Funding: This research received no external funding.

Acknowledgments: We offer our sincere thanks to Peter Morin at Rutgers University for assisting us with the multivariate analyses. We would also like to express our gratitude to our colleagues, Kathleen Kerwin, Robert Kwait, Chris Crosby, Tyler Christensen, and Erin McHale for offering feedback and suggestions on clarity of the manuscript.

Conflicts of Interest: The authors declare no conflict of interest. 


\section{Appendix A}

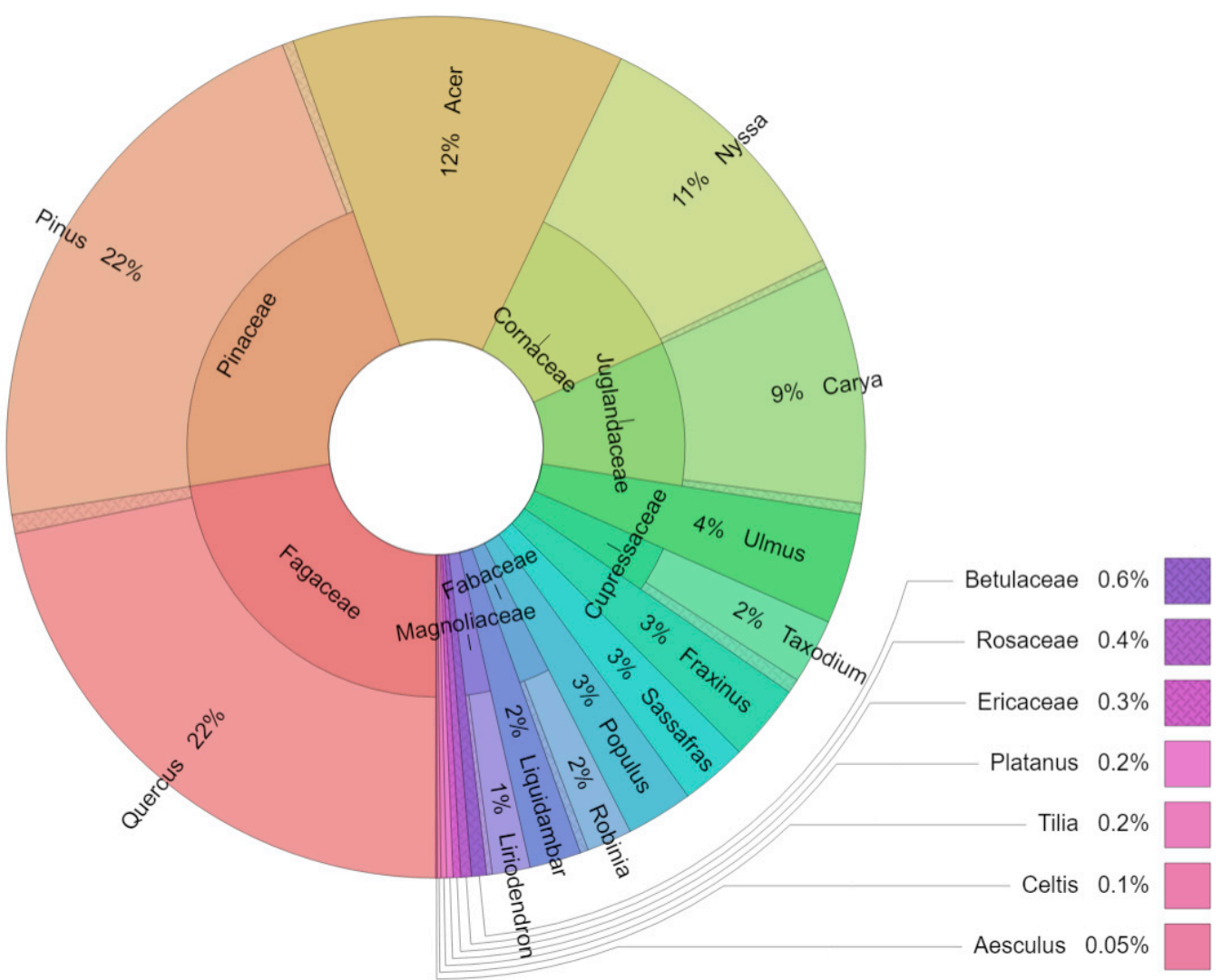

Figure A1. Distribution of tree genera used as roosts by bats of eastern temperate forests $(\mathrm{N}=4228)$.

Table A1. Pairwise Tukey's Honest Significant Difference test p-values for the seven most reported roost-site characteristics eastern temperate forest bats. Colored cells indicate a significant difference $(p<0.05)$. Blue cells indicate a difference between roosting guilds, and green cells indicate differences within guilds. $\mathrm{DBH}=$ diameter at breast height, $\mathrm{T} . \mathrm{Hgt}=$ tree height, R.Hgt = roost entrance height, $\mathrm{CC}=$ canopy closure, Decid $=$ percentage of deciduous trees used as roosts, Snag = percentage of dead trees used as roosts, $\mathrm{Fol}=$ percentage of roosts that were in clumps of foliage.

\begin{tabular}{|c|c|c|c|c|c|c|c|}
\hline Species Pair & DBH & T.Ht & R.Ht & $\mathrm{CC}$ & Decid & Snag & Fol \\
\hline Eptesicus fuscus - Corynorhinus rafinesquii & $<0.0001$ & 0.9639 & 0.9999 & 1.0000 & 0.4085 & 0.6792 & 1.0000 \\
\hline Lasionycteris noctivagans - Corynorhinus rafinesquii & 0.0045 & 0.9934 & 1.0000 & 0.9644 & 0.1918 & 0.9999 & 1.0000 \\
\hline Lasiurus borealis - Corynorhinus rafinesquii & $<0.0001$ & 0.9592 & 0.4567 & 1.0000 & 0.9999 & 0.9714 & $<0.0001$ \\
\hline Lasiurus intermedius - Corynorhinus rafinesquii & 0.0498 & 0.9900 & 0.9992 & 0.9479 & 1.0000 & 0.9983 & $<0.0001$ \\
\hline Lasiurus seminolus - Corynorhinus rafinesquii & $<0.0001$ & 0.8938 & 0.0838 & 1.0000 & $<0.0001$ & 0.9983 & $<0.0001$ \\
\hline Myotis austroriparius - Corynorhinus rafinesquii & 0.1487 & 1.0000 & 0.9256 & 0.9966 & 1.0000 & 1.0000 & 1.0000 \\
\hline Myotis septentrionalis - Corynorhinus rafinesquii & $<0.0001$ & 0.9305 & 0.5664 & 1.0000 & 0.9903 & 0.1896 & 1.0000 \\
\hline Myotis sodalis - Corynorhinus rafinesquii & $<0.0001$ & 1.0000 & 0.0723 & 0.7962 & 0.7977 & 0.0080 & 1.0000 \\
\hline Nycticeius humeralis - Corynorhinus rafinesquii & $<0.0001$ & 0.8844 & 0.0749 & 1.0000 & 0.1694 & 0.6818 & 1.0000 \\
\hline Perimyotis subflavus - Corynorhinus rafinesquii & $<0.0001$ & 1.0000 & 0.0572 & 0.9970 & 1.0000 & 1.0000 & $<0.0001$ \\
\hline Lasionycteris noctivagans - Eptesicus fuscus & 1.0000 & 0.7767 & 1.0000 & 0.9999 & 0.9995 & 0.7167 & 1.0000 \\
\hline Lasiurus borealis - Eptesicus fuscus & 1.0000 & 1.0000 & 0.9990 & 0.9994 & 0.7165 & 0.1480 & $<0.0001$ \\
\hline Myotis lucifugus - Eptesicus fuscus & 0.9999 & 0.9985 & 1.0000 & 1.0000 & 0.9456 & 1.0000 & 1.0000 \\
\hline Myotis septentrionalis - Eptesicus fuscus & 1.0000 & 1.0000 & 1.0000 & 1.0000 & 0.7836 & 1.0000 & 1.0000 \\
\hline
\end{tabular}


Table A1. Cont.

\begin{tabular}{|c|c|c|c|c|c|c|c|}
\hline Species Pair & DBH & T.Ht & R.Ht & $\mathrm{CC}$ & Decid & Snag & Fol \\
\hline Myotis sodalis - Eptesicus fuscus & 0.9994 & 0.9933 & 0.9998 & 1.0000 & 0.8953 & 1.0000 & 1.0000 \\
\hline Nycticeius humeralis - Eptesicus fuscus & 0.9901 & 1.0000 & 0.9968 & 1.0000 & 0.9982 & 0.9990 & 1.0000 \\
\hline Lasiurus borealis - Lasionycteris noctivagans & 1.0000 & 0.8224 & 0.9126 & 0.8210 & 0.3614 & 1.0000 & $<0.0001$ \\
\hline Lasiurus cinereus - Lasionycteris noctivagans & 1.0000 & 1.0000 & 0.0420 & 0.9642 & 0.9997 & 1.0000 & $<0.0001$ \\
\hline Lasiurus intermedius - Lasionycteris noctivagans & 1.0000 & 0.8509 & 1.0000 & 1.0000 & 0.4353 & 1.0000 & $<0.0001$ \\
\hline Myotis lucifugus - Lasionycteris noctivagans & 1.0000 & 0.3774 & 0.9999 & 0.9999 & 0.6629 & 0.7299 & 1.0000 \\
\hline Myotis septentrionalis - Lasionycteris noctivagans & 1.0000 & 0.8201 & 0.9953 & 0.9933 & 0.4148 & 0.6841 & 1.0000 \\
\hline Myotis sodalis - Lasionycteris noctivagans & 1.0000 & 0.9661 & 0.9172 & 1.0000 & 0.5285 & 0.3975 & 1.0000 \\
\hline Nycticeius humeralis - Lasionycteris noctivagans & 0.9996 & 0.7824 & 0.8250 & 0.9927 & 0.8419 & 0.8877 & 1.0000 \\
\hline Perimyotis subflavus - Lasionycteris noctivagans & 1.0000 & 0.9950 & 0.5225 & 1.0000 & 0.2883 & 1.0000 & $<0.0001$ \\
\hline Myotis lucifugus - Lasiurus borealis & 0.9843 & 0.9510 & 0.9999 & 0.9997 & 1.0000 & 0.3353 & $<0.0001$ \\
\hline Myotis septentrionalis - Lasiurus borealis & 0.9560 & 1.0000 & 0.9970 & 0.9217 & 1.0000 & 0.0030 & $<0.0001$ \\
\hline Myotis sodalis - Lasiurus borealis & 0.4913 & 0.9968 & 1.0000 & 0.2186 & 0.9995 & $<0.0001$ & $<0.0001$ \\
\hline Nycticeius humeralis - Lasiurus borealis & 0.2946 & 1.0000 & 1.0000 & 0.9863 & 0.7580 & 0.0325 & $<0.0001$ \\
\hline Perimyotis subflavus - Lasiurus borealis & 1.0000 & 0.9886 & 0.9996 & 0.8858 & 1.0000 & 0.9996 & 0.4902 \\
\hline Lasiurus intermedius - Lasiurus cinereus & 1.0000 & 0.7512 & 0.0082 & 0.9672 & 0.6015 & 1.0000 & 1.0000 \\
\hline Lasiurus seminolus - Lasiurus cinereus & 1.0000 & 1.0000 & 0.9960 & 1.0000 & 0.8563 & 1.0000 & 1.0000 \\
\hline Myotis austroriparius - Lasiurus cinereus & 0.0014 & 0.9977 & 0.0003 & 1.0000 & 0.1574 & 0.9939 & $<0.0001$ \\
\hline Myotis lucifugus - Lasiurus cinereus & 0.9998 & 0.1966 & 0.2150 & 1.0000 & 0.8771 & 0.4231 & $<0.0001$ \\
\hline Myotis septentrionalis - Lasiurus cinereus & 1.0000 & 0.3362 & 0.0298 & 0.9998 & 0.3951 & 0.0580 & $<0.0001$ \\
\hline Myotis sodalis - Lasiurus cinereus & 0.9984 & 0.7724 & 0.0921 & 0.9511 & 0.5683 & 0.0055 & $<0.0001$ \\
\hline Perimyotis subflavus - Lasiurus intermedius & 0.9977 & 0.9932 & 0.1537 & 1.0000 & 1.0000 & 1.0000 & 1.0000 \\
\hline Myotis austroriparius - Lasiurus seminolus & 0.0033 & 0.9924 & 0.0146 & 0.9986 & 0.0001 & 0.9982 & $<0.0001$ \\
\hline Myotis lucifugus - Lasiurus seminolus & 1.0000 & 0.1497 & 0.8376 & 1.0000 & 0.1451 & 0.5183 & $<0.0001$ \\
\hline Myotis septentrionalis - Lasiurus seminolus & 1.0000 & 0.1607 & 0.5201 & 1.0000 & 0.0004 & 0.2092 & $<0.0001$ \\
\hline Myotis sodalis - Lasiurus seminolus & 1.0000 & 0.5736 & 0.8194 & 0.9683 & 0.0008 & 0.0462 & $<0.0001$ \\
\hline Nycticeius humeralis - Lasiurus seminolus & 0.9999 & 0.1338 & 0.9540 & 1.0000 & 0.0201 & 0.5000 & $<0.0001$ \\
\hline Perimyotis subflavus - Lasiurus seminolus & 0.9908 & 0.9457 & 1.0000 & 0.9997 & 0.0005 & 1.0000 & 1.0000 \\
\hline Myotis lucifugus - Myotis austroriparius & 0.1775 & 0.5022 & 0.8698 & 0.9929 & 1.0000 & 0.8401 & 1.0000 \\
\hline Myotis septentrionalis - Myotis austroriparius & $<0.0001$ & 0.8827 & 0.0486 & 0.8699 & 0.9976 & 0.4003 & 1.0000 \\
\hline Myotis sodalis - Myotis austroriparius & $<0.0001$ & 0.9995 & 0.0034 & 0.3331 & 0.9307 & 0.0476 & 1.0000 \\
\hline Nycticeius humeralis - Myotis austroriparius & 0.0004 & 0.8302 & 0.0047 & 0.9386 & 0.3696 & 0.8620 & 1.0000 \\
\hline Perimyotis subflavus - Myotis austroriparius & $<0.0001$ & 1.0000 & 0.0060 & 0.7912 & 1.0000 & 1.0000 & $<0.0001$ \\
\hline Myotis septentrionalis - Myotis lucifugus & 1.0000 & 0.9248 & 1.0000 & 1.0000 & 1.0000 & 1.0000 & 1.0000 \\
\hline Myotis sodalis - Myotis lucifugus & 1.0000 & 0.7098 & 1.0000 & 1.0000 & 1.0000 & 1.0000 & 1.0000 \\
\hline Nycticeius humeralis - Myotis lucifugus & 1.0000 & 0.9496 & 0.9996 & 1.0000 & 0.9972 & 0.9978 & 1.0000 \\
\hline Perimyotis subflavus - Myotis lucifugus & 0.9820 & 0.6444 & 0.9581 & 1.0000 & 1.0000 & 0.6469 & $<0.0001$ \\
\hline Myotis sodalis - Myotis septentrionalis & 0.9992 & 0.9936 & 0.9940 & 0.8859 & 1.0000 & 0.9929 & 1.0000 \\
\hline Nycticeius humeralis - Myotis septentrionalis & 0.9566 & 1.0000 & 0.9463 & 1.0000 & 0.8000 & 0.9979 & 1.0000 \\
\hline Perimyotis subflavus - Myotis septentrionalis & 0.9747 & 0.9852 & 0.6357 & 1.0000 & 0.9999 & 0.0697 & $<0.0001$ \\
\hline Nycticeius humeralis - Myotis sodalis & 0.9999 & 0.9814 & 1.0000 & 0.9417 & 0.9622 & 0.4726 & 1.0000 \\
\hline Perimyotis subflaous - Myotis sodalis & 0.7046 & 1.0000 & 0.9486 & 1.0000 & 0.9918 & 0.0023 & $<0.0001$ \\
\hline Perimyotis subflavus - Nycticeius humeralis & 0.4754 & 0.9694 & 0.9980 & 1.0000 & 0.6663 & 0.3675 & $<0.0001$ \\
\hline
\end{tabular}




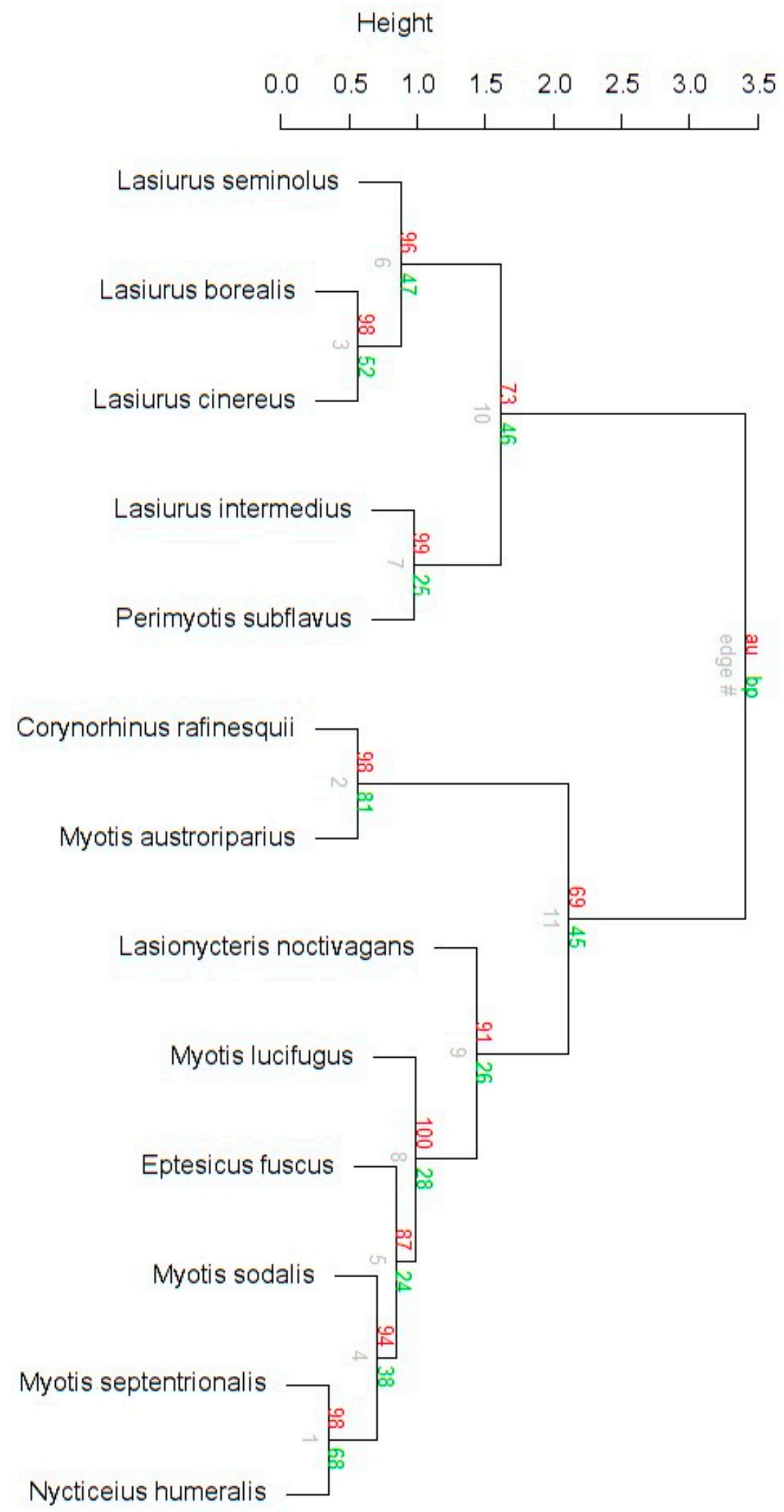

Figure A2. Cluster dendrogram with approximately unbiased (au) p-values in red, bootstrap probabilities (bp) in green, and the edge number labeling the nodes in gray. This figure separates North American eastern temperate forest tree-roosting bats using Ward's method and Euclidean distance. 


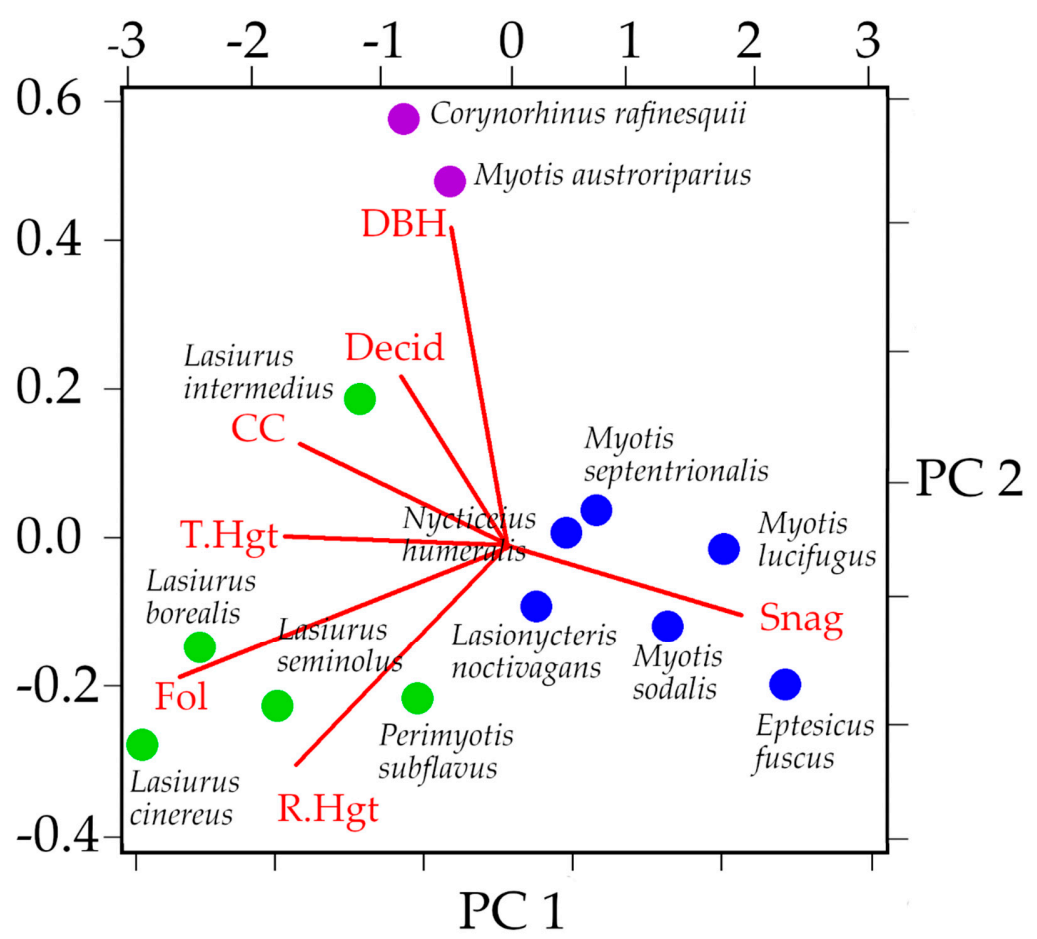

Figure A3. PCA on the correlation matrix of the seven most-reported roost tree characteristics. $\mathrm{CC}=$ canopy closure, $\mathrm{DBH}=$ diameter at breast height, $\mathrm{T} . \mathrm{Hgt}=$ tree height, $\mathrm{R} . \mathrm{Hgt}=$ roost entrance height, Snag = percentage of dead trees used as roosts, Decid = percentage of deciduous trees used as roosts, $\mathrm{Fol}=$ percentage of roosts that were in clumps of foliage.

\section{References}

1. Kunz, T.H. Ecology of Bats; Springer Science \& Business Media: New York, NY, USA, 2013.

2. MammalDiversity.org. Mammal Diversity Database. Available online: www.mammaldiversity.org (accessed on 6 January 2020).

3. Burgin, C.J.; Colella, J.P.; Kahn, P.L.; Upham, N.S. How many species of mammals are there? J. Mammal. 2018, 99, 1-14. [CrossRef]

4. Hill, J.E.; Smith, S.E. Craseonycteris thonglongyai. Mammal. Species 1981, 1-4. [CrossRef]

5. Ingle, N.R.; Heaney, L.R. A key to the bats of the Philippine Islands. Fieldiana Zool. 1992, 69, 1-44.

6. Kunz, T.H.; Braun de Torrez, E.; Bauer, D.; Lobova, T.; Fleming, T.H. Ecosystem services provided by bats. Ann. N. Y. Acad. Sci. 2011, 1223, 1-38. [CrossRef] [PubMed]

7. Maine, J.J.; Boyles, J.G. Bats initiate vital agroecological interactions in corn. Proc. Natl. Acad. Sci. USA 2015, 112, 12438-12443. [CrossRef]

8. Maslo, B.; Valentin, R.; Leu, K.; Kerwin, K.; Hamilton, G.C.; Bevan, A.; Fefferman, N.H.; Fonseca, D.M. Chirosurveillance: The use of native bats to detect invasive agricultural pests. PLoS ONE 2017, 12, e0173321. [CrossRef]

9. Russo, D.; Bosso, L.; Ancillotto, L. Novel perspectives on bat insectivory highlight the value of this ecosystem service in farmland: research frontiers and management implications. Agric. Ecosyst. Environ. 2018, 266, 31-38. [CrossRef]

10. Fleming, T.H.; Geiselman, C.; Kress, W.J. The evolution of bat pollination: A phylogenetic perspective. Ann. Bot. 2009, 104, 1017-1043. [CrossRef]

11. Tremlett, C.J.; Moore, M.; Chapman, M.A.; Zamora-Gutierrez, V.; Peh, K.S.H. Pollination by bats enhances both quality and yield of a major cash crop in Mexico. J. Appl. Ecol. 2019. [CrossRef]

12. Mahandran, V.; Murugan, C.M.; Marimuthu, G.; Nathan, P.T. Seed dispersal of a tropical deciduous Mahua tree, Madhuca latifolia (Sapotaceae) exhibiting bat-fruit syndrome by pteropodid bats. Glob. Ecol. Conserv. Manag. Bats For. 2018, 14, e00396. [CrossRef] 
13. Saldaña-Vázquez, R.A.; Castaño, J.H.; Baldwin, J.; Pérez-Torres, J. Does seed ingestion by bats enhance germination? A new meta-analysis 15 years later. Mammal. Rev. 2019, 49, 201-209. [CrossRef]

14. Boyles, J.G.; Cryan, P.M.; McCracken, G.F.; Kunz, T.H. Economic importance of bats in agriculture. Science 2011, 332, 41-42. [CrossRef] [PubMed]

15. Morton, J.F. The impact of climate change on smallholder and subsistence agriculture. Proc. Natl. Acad. Sci. USA 2007, 104, 19680-19685. [CrossRef]

16. Frick, W.F.; Kingston, T.; Flanders, J. A review of the major threats and challenges to global bat conservation. Ann. N. Y. Acad. Sci. 2019. [CrossRef] [PubMed]

17. Ward, M.; Rhodes, J.R.; Watson, J.E.; Lefevre, J.; Atkinson, S.; Possingham, H.P. Use of surrogate species to cost-effectively prioritize conservation actions. Conserv. Biol. 2019. [CrossRef] [PubMed]

18. Roberge, J.M.; Angelstam, P. Usefulness of the umbrella species concept as a conservation tool. Conserv. Biol. 2004, 18, 76-85. [CrossRef]

19. Seddon, P.J.; Leech, T. Conservation short cut, or long and winding road? A critique of umbrella species criteria. Oryx 2008, 42, 240-245. [CrossRef]

20. Caro, T.; O'Doherty, G. On the use of surrogate species in conservation biology. Conserv. Biol. 1999, 13, 805-814. [CrossRef]

21. Kingston, T. Research priorities for bat conservation in Southeast Asia: A consensus approach. Biodivers. Conserv. 2010, 19, 471-484. [CrossRef]

22. Scanlon, A.T.; Petit, S. Capture success of Fijian bats (Pteropodidae) and their evaluation as umbrella species for conservation. Pac. Conserv. Biol. 2016, 21, 315-326. [CrossRef]

23. Caro, T. Umbrella species: Critique and lessons from East Africa. Anim. Conserv. 2003, 6, 171-181. [CrossRef]

24. Fleishman, E.; Murphy, D.D.; Brussard, P.F. A new method for selection of umbrella species for conservation planning. Ecol. Appl. 2000, 10,569-579. [CrossRef]

25. Favreau, J.M.; Drew, C.A.; Hess, G.R.; Rubino, M.J.; Koch, F.H.; Eschelbach, K.A. Recommendations for assessing the effectiveness of surrogate species approaches. Biodivers. Conserv. 2006, 15, 3949-3969. [CrossRef]

26. Lorch, J.M.; Meteyer, C.U.; Behr, M.J.; Boyles, J.G.; Cryan, P.M.; Hicks, A.C.; Ballmann, A.E.; Coleman, J.T.; Redell, D.N.; Reeder, D.M. Experimental infection of bats with Geomyces destructans causes white-nose syndrome. Nature 2011, 480, 376-378. [CrossRef] [PubMed]

27. Warnecke, L.; Turner, J.M.; Bollinger, T.K.; Lorch, J.M.; Misra, V.; Cryan, P.M.; Wibbelt, G.; Blehert, D.S.; Willis, C.K. Inoculation of bats with European Geomyces destructans supports the novel pathogen hypothesis for the origin of white-nose syndrome. Proc. Natl. Acad. Sci. USA 2012, 109, 6999-7003. [CrossRef] [PubMed]

28. Frick, W.F.; Cheng, T.L.; Langwig, K.E.; Hoyt, J.R.; Janicki, A.F.; Parise, K.L.; Foster, J.T.; Kilpatrick, A.M. Pathogen dynamics during invasion and establishment of white-nose syndrome explain mechanisms of host persistence. Ecology 2017, 98, 624-631. [CrossRef] [PubMed]

29. Park, K.J. Mitigating the impacts of agriculture on biodiversity: Bats and their potential role as bioindicators. Mamm. Biol. 2015, 80, 191-204. [CrossRef]

30. Williams-Guillén, K.; Olimpi, E.; Maas, B.; Taylor, P.J.; Arlettaz, R. Bats in the anthropogenic matrix: Challenges and opportunities for the conservation of Chiroptera and their ecosystem services in agricultural landscapes. In Bats in the Anthropocene: Conservation of Bats in a Changing World; Springer: Cham, Switzerland, 2016; pp. 151-186.

31. O'shea, T.J.; Cryan, P.M.; Hayman, D.T.; Plowright, R.K.; Streicker, D.G. Multiple mortality events in bats: A global review. Mammal. Rev. 2016, 46, 175-190. [CrossRef]

32. Arnett, E.B.; Baerwald, E.F. Impacts of wind energy development on bats: Implications for conservation. In Bat Evolution, Ecology, and Conservation; Springer: New York, NY, USA, 2013; pp. 435-456.

33. Hayes, M.A. Bats killed in large numbers at United States wind energy facilities. BioScience 2013, 63, 975-979.

34. Smallwood, K.S. Comparing bird and bat fatality-rate estimates among North American wind-energy projects. Wildl. Soc. Bull. 2013, 37, 19-33. [CrossRef]

35. Seto, K.C.; Güneralp, B.; Hutyra, L.R. Global forecasts of urban expansion to 2030 and direct impacts on biodiversity and carbon pools. Proc. Natl. Acad. Sci. USA 2012, 109, 16083-16088. [CrossRef] [PubMed]

36. Morrison, M.L.; Marcot, B.; Mannan, W. Wildlife-Habitat Relationships: Concepts and Applications; Island Press: Washington, DC, USA, 2012. 
37. Meyer, C.F.; Struebig, M.J.; Willig, M.R. Responses of tropical bats to habitat fragmentation, logging, and deforestation. In Bats in the Anthropocene: Conservation of Bats in a Changing World; Springer: Cham, Switzerland, 2016; pp. 63-103.

38. Brigham, R.M.; Vonhof, M.J.; Barclay, R.M.; Gwilliam, J.C. Roosting behavior and roost-site preferences of forest-dwelling California bats (Myotis californicus). J. Mammal. 1997, 78, 1231-1239. [CrossRef]

39. Willis, C.K.R.; Brigham, R.M. Physiological and ecological aspects of roost selection by reproductive female hoary bats (Lasiurus cinereus). J. Mammal. 2005, 86, 85-94. [CrossRef]

40. Kurta, A. Bark roost of a male big brown bat, Eptesicus fuscus. Bat Res. News 1994, 35, 63.

41. Perry, R.W.; Thill, R.E. Roost selection by male and female northern long-eared bats in a pine-dominated landscape. For. Ecol. Manag. 2007, 247, 220-226. [CrossRef]

42. Omernik, J.M.; Griffith, G.E. Ecoregions of the conterminous United States: Evolution of a hierarchical spatial framework. Environ. Manag. 2014, 54, 1249-1266. [CrossRef]

43. Gilliam, F.S.; Goodale, C.L.; Pardo, L.H.; Geiser, L.H.; Lilleskov, E.A.; Robin-Abbott, M.; Driscoll, C. Assessment of Nitrogen Deposition Effects Empirical Critical Loads of Nitrogen for Ecoregions of the United States; US Department of Agriculture, F.S., Northern Research Station: Newtown Square, PA, USA, 2011; Volume 80, pp. 99-116.

44. Harvey, M.J.; Altenbach, J.S.; Best, T.L. Bats of the United States and Canada; JHU Press: Baltimore, MD, USA, 2011.

45. IUCN. The IUCN Red List of Threatened Species; Version 2019-3; IUCN: Gland, Switzerland, 2019.

46. COSEWIC. COSEWIC Assessment and Status Report on the Little Brown Myotis (Myotis lucifugus), Northern Myotis (Myotis septentrionalis), and Tri-colored Bat (Perimyotis subflavus) in Canada; COSEWIC: Ottawa, ON, Canada, 2013.

47. Hoofer, S. Molecular phylogenetics of the chiropteran family Vespertilionidae. Ph.D. Thesis, Oklahoma State University, Stillwater, OK, USA, 2003.

48. Suter, W.; Graf, R.F.; Hess, R. Capercaillie (Tetrao urogallus) and avian biodiversity: Testing the umbrella-species concept. Conserv. Biol. 2002, 16, 778-788. [CrossRef]

49. Maslo, B.; Leu, K.; Faillace, C.; Weston, M.; Pover, T.; Schlacher, T. Selecting umbrella species for conservation: A test of habitat models and niche overlap for beach-nesting birds. Biol. Conserv. 2016, 203, $233-242$. [CrossRef]

50. Liu, U.; Kenney, S.; Breman, E.; Cossu, T.A. A multicriteria decision making approach to prioritise vascular plants for species-based conservation. Biol. Conserv. 2019, 234, 221-240. [CrossRef]

51. Betts, B.J. Roosts used by maternity colonies of silver-haired bats in northeastern Oregon. J. Mammal. 1998, 79, 643-650. [CrossRef]

52. Ward, J.H., Jr. Hierarchical grouping to optimize an objective function. J. Am. Stat. Assoc. 1963, 58, $236-244$. [CrossRef]

53. RC Team. A Language and Environment for Statistical Computing; R Foundation for statistical comuting: Vienna, Austria, 2013.

54. Suzuki, R.; Shimodaira, H. Hierarchical Clustering with P-Values via Multiscale Bootstrap Resampling. R Package, 2.0. 2015. Available online: http://CRAN.R-project.org/package=pvclust (accessed on 10 February 2020).

55. McGarigal, K.; Cushman, S.A.; Stafford, S. Multivariate Statistics for Wildlife and Ecology Research; Springer Science \& Business Media: New York, NY, USA, 2013.

56. Badin, H.A. Habitat selection and roosting ranges of northern long-eared bats (Myotis septentrionalis) in an experimental hardwood forest system. Master's Thesis, Ball State University, Muncie, IN, USA, 2014.

57. Bergeson, S.M.; Carter, T.C.; Whitby, M.D. Adaptive Roosting Gives Little Brown Bats an Advantage over Endangered Indiana Bats. Am. Midl. Nat. 2015, 174, 321-330. [CrossRef]

58. Bergeson, S.M.; O'Keefe, J.M.; Haulton, G.S. Managed forests provide roosting opportunities for Indiana bats in south-central Indiana. For. Ecol. Manag. 2018, 427, 305-316. [CrossRef]

59. Boyles, J.G.; Robbins, L.W. Characteristics of summer and winter roost trees used by evening bats (Nycticeius humeralis) in southwestern Missouri. Am. Midl. Nat. 2006, 155, 210-220. [CrossRef]

60. Brack, V., Jr.; Whitaker, J.O., Jr.; Pruitt, S.E. Bats of Hoosier National Forest. Proc. Indiana Acad. Sci. 2004, 113, 76-86.

61. Brack, V. Autumn activity of Myotis sodalis (Indiana bat) in Bland County, Virginia. Northeast. Nat. 2006, 13, 421-434. [CrossRef] 
62. Brandebura, S.C.; Pannkuk, E.L.; Risch, T.S. Indiana Bat (Myotis sodalis) Maternity Colonies in Arkansas. Southeast. Nat. 2011, 10, 529-532. [CrossRef]

63. Britzke, E.R.; Harvey, M.J.; Loeb, S.C. Indiana bat, Myotis sodalis, maternity roosts in the southern United States. Southeast. Nat. 2003, 2, 235-242. [CrossRef]

64. Britzke, E.R.; Hicks, A.C.; Von Oettingen, S.L.; Darling, S.R. Description of spring roost trees used by female Indiana bats (Myotis sodalis) in the Lake Champlain Valley of Vermont and New York. Am. Midl. Nat. 2006, 155, 181-187. [CrossRef]

65. Broders, H.G.; Forbes, G.J. Interspecific and intersexual variation in roost-site selection of northern long-eared and little brown bats in the Greater Fundy National Park Ecosystem. J. Wildl. Manag. 2004, 68, 602-610. [CrossRef]

66. Callahan, E.V.; Drobney, R.D.; Clawson, R.L. Selection of summer roosting sites by Indiana bats (Myotis sodalis) in Missouri. J. Mammal. 1997, 78, 818-825. [CrossRef]

67. Carter, T.; Menzel, M.; Chapman, B.; Miller, K. Summer foraging and roosting behavior of an eastern pipistrelle, Pipistrellus subflavus. Bat Res. News 1999, 40, 5-6.

68. Carter, T.C.; Feldhamer, G.A. Roost tree use by maternity colonies of Indiana bats and northern long-eared bats in southern Illinois. For. Ecol. Manag. 2005, 219, 259-268. [CrossRef]

69. Carver, B.D.; Ashley, N. Roost Tree Use by Sympatric Rafinesque's Big-eared Bats (Corynorhinus rafinesquii) and Southeastern Myotis (Myotis austroriparius). Am. Midl. Nat. 2008, 160, 364-373. [CrossRef]

70. Clement, M.J.; Castleberry, S.B. Southeastern myotis (Myotis austroriparius) roost selection in cypress-gum swamps. Acta Chiropterol. 2013, 15, 133-141. [CrossRef]

71. Clement, M.J.; Castleberry, S.B. Divergent Roosting Habits of Rafinesque's Big-eared Bat and Southeastern Myotis During Winter Floods. Am. Midl. Nat. 2013, 170, 158-170. [CrossRef]

72. Clement, M.J.; Castleberry, S.B. Summer tree roost selection by Rafinesque's big-eared bat. J. Wildl. Manag. 2013, 77, 414-422. [CrossRef]

73. Coleman, L.S.; Morris, K.M.; Castleberry, S.B. Characteristics of Lasiurus intermedius (Northern Yellow Bat) Roosts on Sapelo Island, Georgia. Southeast. Nat. 2012, 11, 534-536. [CrossRef]

74. Duchamp, J.E.; Sparks, D.W.; Whitaker, J.O. Foraging-habitat selection by bats at an urban-rural interface: Comparison between a successful and a less successful species. Can. J. Zool. 2004, 82, 1157-1164. [CrossRef]

75. Elmore, L.W.; Miller, D.A.; Vilella, F.J. Selection of diurnal roosts by red bats (Lasiurus borealis) in an intensively managed pine forest in Mississippi. For. Ecol. Manag. 2004, 199, 11-20. [CrossRef]

76. Fleming, H.L.; Jones, J.C.; Belant, J.L.; Richardson, D.M. Multi-scale Roost Site Selection by Rafinesque's Big-eared Bat (Corynorhinus rafinesquii) and Southeastern Myotis (Myotis austroriparius) in Mississippi. Am. Midl. Nat. 2013, 169, 43-55. [CrossRef]

77. Ford, W.M. Summer Roost-Tree Selection by a Male Indiana Bat on the Fernow Experimental Forest; US Dept. of Agriculture, Forest Service, Northeastern Research Station: Newtown Square, PA, USA, 2002; Volume 378.

78. Ford, W.M.; Owen, S.F.; Edwards, J.W.; Rodrigue, J.L. Robinia pseudoacacia (Black locust) as day-roosts of male Myotis septentrionalis (Northern Bats) on the Fernow Experimental Forest, West Virginia. Northeast. Nat. 2006, 13, 15-24. [CrossRef]

79. Foster, R.W.; Kurta, A. Roosting ecology of the northern bat (Myotis septentrionalis) and comparisons with the endangered Indiana bat (Myotis sodalis). J. Mammal. 1999, 80, 659-672. [CrossRef]

80. Gardner, J.E.; Garner, J.D.; Hofmann, J.E. Summer Roost Selection and Roosting Behavior of Myotis sodalis (Indiana bat) in Illinois; INHS Center for Biogeographic Information and IDNR Division of Natural Heritage: Champaign, IL, USA, 1991.

81. Gardner, J.E.; Garner, J.D.; Hofmann, J.E.; Krejca, J.K.; Robinson, S.E. Distribution and status of Myotis austroriparius (southeastern bat) in Illinois; Illinois Natural History Survey and Illinois Department of Conservation: Champaign, IL, USA, 1992.

82. Germain, M.J.S.; Kniowski, A.B.; Silvis, A.; Ford, W.M. Who Knew? First Myotis sodalis (Indiana Bat) Maternity Colony in the Coastal Plain of Virginia. Northeast. Nat. 2017, 24, N5-N10. [CrossRef]

83. Gooding, G.; Langford, J.R. Characteristics of tree roosts of Rafinesque's big-eared bat and southeastern bat in northeastern Louisiana. Southwest. Nat. 2004, 49, 61-67. [CrossRef]

84. Gumbert, M.W.; O’Keefe, J.M.; MacGregor, J.R. Roost fidelity in Kentucky; Bat Conservation International: Austin, TX, USA, 2002; pp. 143-152. 
85. Hann, Z.A.; Hosler, M.J.; Moosman, P.R., Jr. Roosting Habits of Two Lasiurus borealis (Eastern Red Bat) in the Blue Ridge Mountains of Virginia. Northeast. Nat. 2017, 24, N15-N18. [CrossRef]

86. Hein, C.D.; Castleberry, S.B.; Miller, K.V. Sex-specific summer roost-site selection by seminole bats in response to landscape-level forest management. J. Mammal. 2008, 89, 964-972. [CrossRef]

87. Hein, C.D.; Miller, K.V.; Castleberry, S.B. Evening Bat Summer Roost-Site Selection on a Managed Pine Landscape. J. Wildl. Manag. 2009, 73, 511-517. [CrossRef]

88. Henderson, L.E.; Broders, H.G. Movements and resource selection of the northern long-eared myotis (Myotis septentrionalis) in a forest-agriculture landscape. J. Mammal. 2008, 89, 952-963. [CrossRef]

89. Hobson, C.S.; Holland, J.N. Post-hibernation movement and foraging habitat of a male Indiana bat, Myotis sodalis (Chiroptera: Vespertilionidae), in western Virginia. Brimleyana. 1995. Available online: https://hdl.handle.net/1911/21696 (accessed on 10 February 2020).

90. Hutchinson, J.T. Bats of Archbold Biological Station and notes on some roost sites. Fla. Field Nat. 2006, 34, 48-51.

91. Istvanko, D.R.; Risch, T.S.; Rolland, V. Sex-specific foraging habits and roost characteristics of Nycticeius humeralis in north-central Arkansas. J. Mammal. 2016, 97, 1336-1344. [CrossRef]

92. Jachowski, D.S.; Rota, C.T.; Dobony, C.A.; Ford, W.M.; Edwards, J.W. Seeing the Forest through the Trees: Considering Roost-Site Selection at Multiple Spatial Scales. PLoS ONE 2016, 11. [CrossRef] [PubMed]

93. Johnson, J.B.; Edwards, J.W.; Ford, W.M.; Gates, J.E. Roost tree selection by northern myotis (Myotis septentrionalis) maternity colonies following prescribed fire in a Central Appalachian Mountains hardwood forest. For. Ecol. Manag. 2009, 258, 233-242. [CrossRef]

94. Johnson, J.B.; Ford, W.M.; Rodrigue, J.L.; Edwards, J.W.; Johnson, C.M. Roost Selection by Male Indiana Myotis Following Forest Fires in Central Appalachian Hardwoods Forests. J. Fish Wildl. Manag. 2010, 1, 111-121. [CrossRef]

95. Johnson, J.S. Foraging and Roosting Behaviors of Rafinesque's Big-eared Bat (Corynorhinus rafinesquii) at the Northern Edge of the Species Range. Ph.D. Thesis, University of Kentuck, Lexington, KY, USA, 2012.

96. Johnson, J.S.; Kropczynski, J.N.; Lacki, M.J.; Langlois, G.D. Social networks of Rafinesque's big-eared bats (Corynorhinus rafinesquii) in bottomland hardwood forests. J. Mammal. 2012, 93, 1545-1558. [CrossRef]

97. Kaarakka, H.M. Notes on Capture and Roost Characteristics of Three Female Evening Bats (Nycticeius humeralis) in Southern Wisconsin: An Expanding Species? Am. Midl. Nat. 2018, 180, 168-173. [CrossRef]

98. Krynak, T.J. Bat habitat use and roost tree selection for northern long-eared myotis (Myotis septentrionalis) in North-Central Ohio. Master's Thesis, University Heights, Cuyahoga County, OH, USA, 2010.

99. Kurta, A.; Foster, R.; Hough, E.; Winhold, L. The evening bat (Nycticeius humeralis) on the northern edge of its range-A maternity colony in Michigan. Am. Midl. Nat. 2005, 154, 264-267. [CrossRef]

100. Kurta, A.; Kath, J.; Smith, E.L.; Foster, R.; Orick, M.W.; Ross, R. A maternity roost of the endangered Indiana bat (Myotis sodalis) in an unshaded, hollow, sycamore tree (Platanus occidentalis). Am. Midl. Nat. 1993, 130, 405-407. [CrossRef]

101. Kurta, A.; King, D.; Teramino, J.A.; Stribley, J.M.; Williams, K.J. Summer roosts of the endangered Indiana bat (Myotis sodalis) on the northern edge of its range. Am. Midl. Nat. 1993, 129, 132-138. [CrossRef]

102. Kurta, A.; Williams, K.J.; Mies, R. Ecological, behavioural, and thermal observations of a peripheral population of Indiana bats (Myotis sodalis). Available online: https://www.for.gov.bc.ca/hfd/pubs/Docs/Wp/Wp23/Wp 23_11.pdf (accessed on 10 February 2020).

103. Lacki, M.J.; Cox, D.R.; Dodd, L.E.; Dickinson, M.B. Response of Northen bats (Myotis septentrionalis) to Prescribed Fires In Eastern Kentucky Forests. J. Mammal. 2009, 90, 1165-1175. [CrossRef]

104. Leput, D.W. Eastern red bat (Lasiurus borealis) and eastern pipistrelle (Pipistrellus subflavus) maternal roost selection: implications for forest management. Master's Thesis, Clemson University Clemson, Clemson, SC, USA, 2004.

105. Lereculeur, A.E. Summer roosting ecology of the northern long-eared bat (Myotis septentrionalis) at Catoosa Wildlife Management Area. Master's Thesis, Tennessee Technological University, Cookeville, TN, USA, 2013.

106. Limpert, D.L.; Birch, D.L.; Scott, M.S.; Andre, M.; Gillam, E. Tree selection and landscape analysis of eastern red bat day roosts. J. Wildl. Manag. 2007, 71, 478-486. [CrossRef]

107. Loeb, S.C. Adaptive response to land-use history and roost selection by Rafinesque's big-eared bats. J. Mammal. 2017, 98, 560-571. [CrossRef] 
108. Lucas, J.S.; Loeb, S.C.; Jodice, P.G.R. Roost selection by Rafinesque's big-eared bats (Corynorhinus rafinesquii) in a pristine habitat at three spatial scales. Acta Chiropterol. 2015, 17, 131-141. [CrossRef]

109. MacGregor, J.R.; Kiser, J.D.; Gumbert, M.W.; Reed, T.O. Autumn roosting habitat of male Indiana bats (Myotis sodalis) in a managed forest setting in Kentucky. In Proceedings of the 12th Central Hardwood Forest Conference, Lexington, KY, USA, 28 February-2 March 1999; USDA Forest Service, Southern Research Station: Asheville, NC, USA, 1999; pp. 169-170.

110. Mager, K.J.; Nelson, T.A. Roost-site selection by eastern red bats (Lasiurus borealis). Am. Midl. Nat. 2001, 145, 120-126. [CrossRef]

111. Menzel, M.A.; Carter, T.C.; Chapman, B.R.; Laerm, J. Quantitative comparison of tree roosts used by red bats (Lasiurus borealis) and Seminole bats (L-seminolus). Can. J. Zool. 1998, 76, 630-634. [CrossRef]

112. Menzel, M.A.; Carter, T.C.; Ford, W.M.; Chapman, B.R. Tree-roost characteristics of subadult and female adult evening bats (Nycticeius humeralis) in the Upper Coastal Plain of South Carolina. Am. Midl. Nat. 2001, 145, 112-119. [CrossRef]

113. Menzel, M.A.; Carter, T.C.; Ford, W.M.; Chapman, B.R.; Ozier, J. Summer roost tree selection by eastern red, seminole, and evening bats in the upper coast plain of South Carolina. Proc. Annu. Conf. Southeast. Assoc. Fish Wildl. Agencies 2000, 54, 304-313.

114. Menzel, M.A.; Owen, S.F.; Ford, W.M.; Edwards, J.W.; Wood, P.B.; Chapman, B.R.; Miller, K.V. Roost tree selection by northern long-eared bat (Myotis septentrionalis) maternity colonies in an industrial forest of the central Appalachian mountains. For. Ecol. Manag. 2002, 155, 107-114. [CrossRef]

115. Miles, A.C.; Castleberry, S.B.; Miller, D.A.; Conner, L.M. Multi-scale roost-site selection by evening bats on pine-dominated landscapes in southwest Georgia. J. Wildl. Manag. 2006, 70, 1191-1199. [CrossRef]

116. Mormann, B.M.; Robbins, L.W. Winter roosting ecology of eastern red bats in southwest Missouri. J. Wildl. Manag. 2007, 71, 213-217. [CrossRef]

117. Muİnzer, O.M. Ecology of the Evening Bat (Nycticeius Humeralis) at the Northern Edge of the Range. Master's Thesis, Eastern Michigan University, Ypsilanti, MI, USA, 2008; p. 166.

118. O'Keefe, J.M.; Loeb, S.C.; Lanham, J.D.; Hill, H.S. Macrohabitat factors affect day roost selection by eastern red bats and eastern pipistrelles in the southern Appalachian Mountains, USA. For. Ecol. Manag. 2009, 257, 1757-1763. [CrossRef]

119. O'Keefe, J.M.; Loeb, S.C.J.F.E.; Management. Indiana bats roost in ephemeral, fire-dependent pine snags in the southern Appalachian Mountains, USA. For. Ecol. Manag. 2017, 391, 264-274. [CrossRef]

120. Palm, J. Indiana bat (Myotis sodalis) summer roost tree selection and habitat use in the Champlain Valley of Vermont. Doctoral Dissertation, Antioch New England Graduate School, Keene, NH, USA, 2003.

121. Perry, R.W. Summer roosting by adult male seminole bats in the ouachita mountains, Arkansas. Am. Midl. Nat. 2007, 158, 361-368. [CrossRef]

122. Perry, R.W.; Brandebura, S.C.; Risch, T.S. Selection of tree roosts by male Indiana bats during the autumn swarm in the Ozark Highlands, USA. Wildl. Soc. Bull. 2016, 40, 78-87. [CrossRef]

123. Perry, R.W.; Saugey, D.A.; Crump, B.G. Winter Roosting Ecology of Silver-haired Bats in an Arkansas Forest. Southeast. Nat. 2010, 9, 563-572. [CrossRef]

124. Perry, R.W.; Thill, R.E. Roost characteristics of hoary bats in Arkansas. Am. Midl. Nat. 2007, 158, $132-138$. [CrossRef]

125. Perry, R.W.; Thill, R.E. Tree roosting by male and female eastern pipistrelles in a forested landscape. J. Mammal. 2007, 88, 974-981. [CrossRef]

126. Perry, R.W.; Thill, R.E. Roost selection by Big Brown Bats in Forests of Arkansas: Importance of Pine Snags and Open Forest Habitats to Males. Southeast. Nat. 2008, 7, 607-618. [CrossRef]

127. Perry, R.W.; Thill, R.E. Diurnal Roosts of Male Evening Bats (Nycticeius humeralis) in Diversely Managed Pine-Hardwood Forests. Am. Midl. Nat. 2008, 160, 374-385. [CrossRef]

128. Perry, R.W.; Thill, R.E.; Carter, S.A. Sex-specific roost selection by adult red bats in a diverse forested landscape. For. Ecol. Manag. 2007, 253, 48-55. [CrossRef]

129. Rice, C.L. Roosting Ecology of Corynorphinus Rafinesquii (Rafinesque's Big-Eared Bat) and Myotis Austroriparius (Southeastern Myotis) in Tree Cavities Found in a Northeastern Louisiana Bottomland Hardwood Forest Streambed. Master's Thesis, University of Louisiana, Monroe, LA, USA, 2009. 
130. Roby, P.L.; Gumbert, M.W.; Sewell, P.L.; Brewer, S.W. Characteristics of roosts used by Rafinesque's big-eared bat (Corynorhinus rafinesquii) on camp Mackall, North Carolina. Conserv. Manag. East. Big-Eared Bats-US For. Serv. Gen. Technol. Rep. SRS 2011, 145, 101-110.

131. Rojas, V.G.; O'Keefe, J.M.; Loeb, S.C. Baseline Capture Rates and Roosting Habits of Myotis septentrionalis (Northern Long-Eared Bat) Prior to White-Nose Syndrome Detection in the Southern Appalachians. Southeast. Nat. 2017, 16, 140-148. [CrossRef]

132. Sasse, D.B.; Pekins, P.J. Summer roosting ecology of northern long-eared bats (Myotis septentrionalis) in the White Mountain National Forest. In Proceedings of the Bats and Forests Symposium, Victoria, BC, Canada, 19-21 October 1995.

133. Schaefer, K. Characteristics of Roost Tree Use by the Tri-Colored Bat (Perimyotis subflavus) Post-White-Nose Syndrome in the Four Rivers Watershed. Master's Thesis 2016.

134. Schroder, E.S.; Ekanayake, D.B.; Romano, S.P. Indiana bat maternity roost habitat preference within Midwestern United States upland Oak-Hickory (Quercus-Carya) forests. For. Ecol. Manag. 2017, 404, 65-74. [CrossRef]

135. Silvis, A.; Ford, W.M.; Britzke, E.R.; Beane, N.R.; Johnson, J.B. Forest succession and maternity day roost selection by Myotis septentrionalis in a mesophytic hardwood forest. Int. J. For. Res. 2012, 2012. [CrossRef]

136. Sparks, D.W.; Ritzi, C.M.; Everson, B.L. Nocturnal behavior and roosting ecology of a juvenile Lasiurus cinereus near Indianapolis, Indiana. Proc. Indiana Acad. Sci. 2005, 114, 70-72.

137. Stuemke, L.A.; Comer, C.E.; Morrison, M.L.; Conway, W.C.; Maxey, R.W. Roosts of Rafinesque's Big-Eared Bats and Southeastern Myotis in East Texas. Southeast. Nat. 2014, 13, 159-171. [CrossRef]

138. Swingen, M.; Baker, R.; Catton, T.; Kirschbaum, K.; Nordquist, G.; Dirks, B.; Moen, R. Preliminary Summary of 2015 Northern Long-eared Bat Research in Minnesota; NRRI Technical Report No. NRRI/TR-2015/44; University of Minnesota Duluth: Duluth, MN, USA, 2015.

139. Swingen, M.; Baker, R.; Catton, T.; Kirschbaum, K.; Nordquist, G.; Dirks, B.; Moen, R. Summary of 2016 Northern Long-eared Bat Research in Minnesota. Available online: https: //www.google.com.hk/url?sa=t\&rct=j\&q=\&esrc=s\&source=web\&cd=1\&ved=2ahUKEwi7t_in-PDnAhXU fd4KHR3cBo8QFjAAegQIARAB\&url=https $\% 3 \mathrm{~A} \% 2 \mathrm{~F} \% 2 \mathrm{Ffiles}$. dnr.state.mn.us $\% 2 \mathrm{Feco} \% 2 \mathrm{Fnongame} \% 2 \mathrm{Fp}$ rojects\%2Fconsgrant_reports\%2F2016\%2F2016_swingen.pdf\&usg=AOvVaw2jv7phKVVt0KPTmN1xtk2j (accessed on 10 February 2020).

140. Thalken, M.M.; Lacki, M.J. Tree roosts of northern long-eared bats following white-nose syndrome. J. Wildl. Manag. 2018, 82, 629-638. [CrossRef]

141. Timpone, J.C.; Boyles, J.G.; Murray, K.L.; Aubrey, D.P.; Robbins, L.W. Overlap in Roosting Habits of Indiana Bats (Myotis sodalis) and Northern Bats (Myotis septentrionalis). Am. Midl. Nat. 2010, 163, 115-123. [CrossRef]

142. Timpone, J.C.; Boyles, J.G.; Robbins, L.W. Potential for niche overlap in roosting sites between Nycticeius humeralis (Evening bats) and Eptesicus fuscus (Big brown bats). Northeast. Nat. 2006, 13, 597-602. [CrossRef]

143. Trousdale, A.W.; Beckett, D.C. Characteristics of tree roosts of Rafinesque's big-eared bat (Corynorhinus rafinesquii) in southeastern Mississippi. Am. Midl. Nat. 2005, 154, 442-449. [CrossRef]

144. Veilleux, J.P.; Moosman, P.R.; Reynolds, D.S.; LaGory, K.E.; Walston, L.J. Observations of Summer Roosting and Foraging Behavior of a Hoary Bat (Lasiurus cinereus) in Southern New Hampshire. Northeast. Nat. 2009, 16, 148-152. [CrossRef]

145. Veilleux, J.P.; Whitaker, J.O.; Veilleux, S.L. Tree-roosting ecology of reproductive female eastern pipistrelles, Pipistrellus subflavus, in Indiana. J. Mammal. 2003, 84, 1068-1075. [CrossRef]

146. Veilleux, S.L. Tree-roosting Ecology and Natural History of Adult Female Evening Bats, Nycticeius Humeralis, in Indiana. Ph.D. Thesis, Indiana State University, Terre Haute, IN, USA, 2007.

147. Watrous, K.S.; Donovan, T.M.; Mickey, R.M.; Darling, S.R.; Hicks, A.C.; Von Oettingen, S.L. Predicting minimum habitat characteristics for the Indiana bat in the Champlain Valley. J. Wildl. Manag. 2006, 70, 1228-1237. [CrossRef]

148. Whitaker, J.O., Jr.; Gummer, S.L. Current status of the evening bat, Nycticeius humeralis, in Indiana. Proc. Indiana Acad. Sci. 2003, 112, 55-60.

149. Whitaker, J.O., Jr.; Sparks, D.W. Roosts of Indiana bats (Myotis sodalis) near the Indianapolis international airport (1997-2001). Proc. Indiana Acad. Sci. 2008, 117, 193-202. 
150. Lacki, M.J.; Baker, M.D. A prospective power analysis and review of habitat characteristics used in studies of tree-roosting bats. Acta Chiropterol. 2003, 5, 199-208. [CrossRef]

151. Lacki, M.J.; Cox, D.R.; Dickinson, M. Meta-analysis of summer roosting characteristics of two species of Myotis bats. Am. Midl. Nat. 2009, 318-326. [CrossRef]

152. Kalcounis-Rüppell, M.C.; Psyllakis, J.M.; Brigham, R.M. Tree roost selection by bats: An empirical synthesis using meta-analysis. Wildl. Soc. Bull. 2005, 33, 1123-1132. [CrossRef]

153. Nad'o, L.; Kaňuch, P. Roost site selection by tree-dwelling bats across biogeographical regions: An updated meta-analysis with meta-regression. Mammal. Rev. 2015, 45, 215-226. [CrossRef]

154. Humphrey, S.R.; Cope, J.B. Survival rates of the endangered Indiana bat, Myotis sodalis. J. Mammal. 1977, 58, 32-36. [CrossRef]

155. Humphrey, S.R.; Richter, A.R.; Cope, J.B. Summer habitat and ecology of the endangered Indiana bat, Myotis sodalis. J. Mammal. 1977, 58, 334-346. [CrossRef]

156. LaVal, R.K.; Clawson, R.L.; LaVal, M.L.; Caire, W. Foraging behavior and nocturnal activity patterns of Missouri bats, with emphasis on the endangered species Myotis grisescens and Myotis sodalis. J. Mammal. 1977, 58, 592-599. [CrossRef]

157. Cope, J.B.; Humphrey, S.R. Spring and autumn swarming behavior in the Indiana bat, Myotis sodalis. J. Mammal. 1977, 58, 93-95. [CrossRef]

158. Reynolds, R.J.; Powers, K.E.; Orndorff, W.; Ford, W.M.; Hobson, C.S. Changes in rates of capture and demographics of Myotis septentrionalis (northern long-eared bat) in western Virginia before and after onset of white-nose syndrome. Northeast. Nat. 2016, 23, 195-204. [CrossRef]

159. Klug, B.J.; Goldsmith, D.A.; Barclay, R.M.R. Roost selection by the solitary, foliage-roosting hoary bat (Lasiurus cinereus) during lactation. Can. J. Zool. 2012, 90, 329-336. [CrossRef]

160. Betts, B.J. Roosting behaviour of silver-haired bats (Lasionycteris noctivagans) and big brown bats (Eptesicus fuscus) in northeast Oregon. In Bats and Forests Symposium; British Columbia Ministry of Forests: Victoria, BC, Canada, 2000; pp. 55-61.

161. Jimenez, C. Identifying and Characterizing Roosts of Lasiurus ega and Lasiurus intermedius. Available online: https://asu-ir.tdl.org/handle/2346.1/30538 (accessed on 10 February 2020).

162. Spencer, S.G.; Choucair, P.C.; Chapman, B.R. Northward Expansion of the Southern Yellow Bat, Lasiurus ega, in Texas. Southwest. Nat. 1988, 33, 493. [CrossRef]

163. Waag, A.G. A Novel Approach to Assessing Abundance and Behavior in Summer Populations of Little Brown Myotis in Yellowstone National Park. Master's Thesis, Ohio University, Athens, OH, USA, 2018.

164. Fagan, K.E.; Willcox, E.V.; Tran, L.T.; Bernard, R.F.; Stiver, W.H. Roost selection by bats in buildings, Great Smoky Mountains National Park. J. Wildl. Manag. 2018, 82, 424-434. [CrossRef]

165. Webber, Q.M.; Brigham, R.M.; Park, A.D.; Gillam, E.H.; O'Shea, T.J.; Willis, C.K. Social network characteristics and predicted pathogen transmission in summer colonies of female big brown bats (Eptesicus fuscus). Behav. Ecol. Sociobiol. 2016, 70, 701-712. [CrossRef]

166. Pfeiffer, M.J. Bats, People, and Buildings: Issues and Opportunities; US Department of Agriculture, Forest Service, Forest Products Laboratory: Madison, WI, USA, 2019; pp. 1-9.

167. Lacki, M. Restoration of Legacy Trees as Roosting Habitat for Myotis Bats in Eastern North American Forests. Diversity 2018, 10, 29. [CrossRef]

168. Kerth, G.; Weissmann, K.; König, B. Day roost selection in female Bechstein's bats (Myotis bechsteinii): A field experiment to determine the influence of roost temperature. Oecologia 2001, 126, 1-9. [CrossRef]

169. Boyles, J.G. Describing roosts used by forest bats: The importance of microclimate. Acta Chiropterol. 2007, 9, 297-303. [CrossRef]

170. MacPhee, C.; Kershaw, J.A.; Weiskittel, A.R.; Golding, J.; Lavigne, M. Comparison of approaches for estimating individual tree height-diameter relationships in the Acadian forest region. For. Int. J. For. Res. 2017, 91, 132-146. [CrossRef]

171. Sharma, R.P.; Vacek, Z.; Vacek, S. Modelling tree crown-to-bole diameter ratio for Norway spruce and European beech. Silva Fenn 2017, 51, 1740. [CrossRef]

172. Otto, M.S.; Becker, N.I.; Encarnacao, J.A. Roost characteristics as indicators for heterothermic behavior of forest-dwelling bats. Ecol. Res. 2016, 31, 385-391. [CrossRef]

173. Suarez-Rubio, M.; Ille, C.; Bruckner, A.; evolution. Insectivorous bats respond to vegetation complexity in urban green spaces. Ecology 2018, 8, 3240-3253. [CrossRef] 
174. Jung, K.; Kaiser, S.; Böhm, S.; Nieschulze, J.; Kalko, E.K. Moving in three dimensions: Effects of structural complexity on occurrence and activity of insectivorous bats in managed forest stands. J. Appl. Ecol. 2012, 49, 523-531. [CrossRef]

175. Otto, M.S.; Becker, N.I.; Encarnação, J.A. Stage of pregnancy dictates heterothermy in temperate forest-dwelling bats. J. Therm. Biol. 2015, 47, 75-82. [CrossRef]

176. Elmore, L.W.; Miller, D.A.; Vilella, F.J. Foraging area size and habitat use by red bats (Lasiurus borealis) in an intensively managed pine landscape in Mississippi. Am. Midl. Nat. 2005, 153, 405-417. [CrossRef]

177. Thalken, M.M.; Lacki, M.J.; Yang, J. Landscape-scale distribution of tree roosts of the northern long-eared bat in Mammoth Cave National Park, USA. Landsc. Ecol. 2018, 33, 1103-1115. [CrossRef]

178. Sherman, A. Corynorhinus rafinesquii and Myotis austroriparius artificial roost characteristics in southwestern Mississippi. Master's Thesis, Jackson State University, Jackson, MS, USA, 2004.

179. Whitaker, J.O., Jr.; Sparks, D.W.; Brack, V., Jr. Bats of the Indianapolis International Airport Area, 1991-2001. Proc. Indiana Acad. Sci. 2004, 113, 151-161.

180. Whitaker, J.O.; Gummer, S.L. Population structure and dynamics of big brown bats (Eptesicus fuscus) hibernating in buildings in Indiana. Am. Midl. Nat. 2000, 143, 389-397. [CrossRef]

181. Riskin, D.K.; Pybus, M.J. The use of exposed diurnal roosts in Alberta by the little brown bat, Myotis lucifugus. Can. J. Zool. 1998, 76, 767-770. [CrossRef]

182. Thomson, C.E. Myotis sodalis. Mammalian Species 1982, 1-5. [CrossRef]

183. USFWS. Endangered and threatened wildlife and plants; threatened status for the Northern Long-eared Bat with 4(d) rule. Fed. Regist. 2015, 80, 17974-18033.

184. Johnson, J.S.; Lacki, M.J. Effects of reproductive condition, roost microclimate, and weather patterns on summer torpor use by a vespertilionid bat. Ecol. Evol. 2014, 4, 157-166. [CrossRef]

185. Turner, G.G.; Reeder, D.; Coleman, J.T. A Five-year Assessment of Mortality and Geographic Spread of White-Nose Syndrome in North American Bats, with a Look at the Future. Update of White-Nose Syndrome in Bats. Bat Res. News 2011, 52, 13.

186. Alston, J.M.; Abernethy, I.M.; Keinath, D.A.; Goheen, J.R. Roost selection by male northern long-eared bats (Myotis septentrionalis) in a managed fire-adapted forest. For. Ecol. Manag. 2019, 446, 251-256. [CrossRef]

187. Silvis, A.; Perry, R.; Ford, W.M. Relationships of Three Species of Bats Impacted by White-Nose Syndrome to Forest Condition and Management; USDA, Ed.; Forest Service: Southern Research Station, Asheville, NC, USA, 2016; Volume 214, pp. 1-48.

188. Carter, T.C. Indiana bats in the Midwest: The importance of hydric habitats. J. Wildl. Manag. 2006, 70, 1185-1190. [CrossRef]

(C) 2020 by the authors. Licensee MDPI, Basel, Switzerland. This article is an open access article distributed under the terms and conditions of the Creative Commons Attribution (CC BY) license (http://creativecommons.org/licenses/by/4.0/). 